
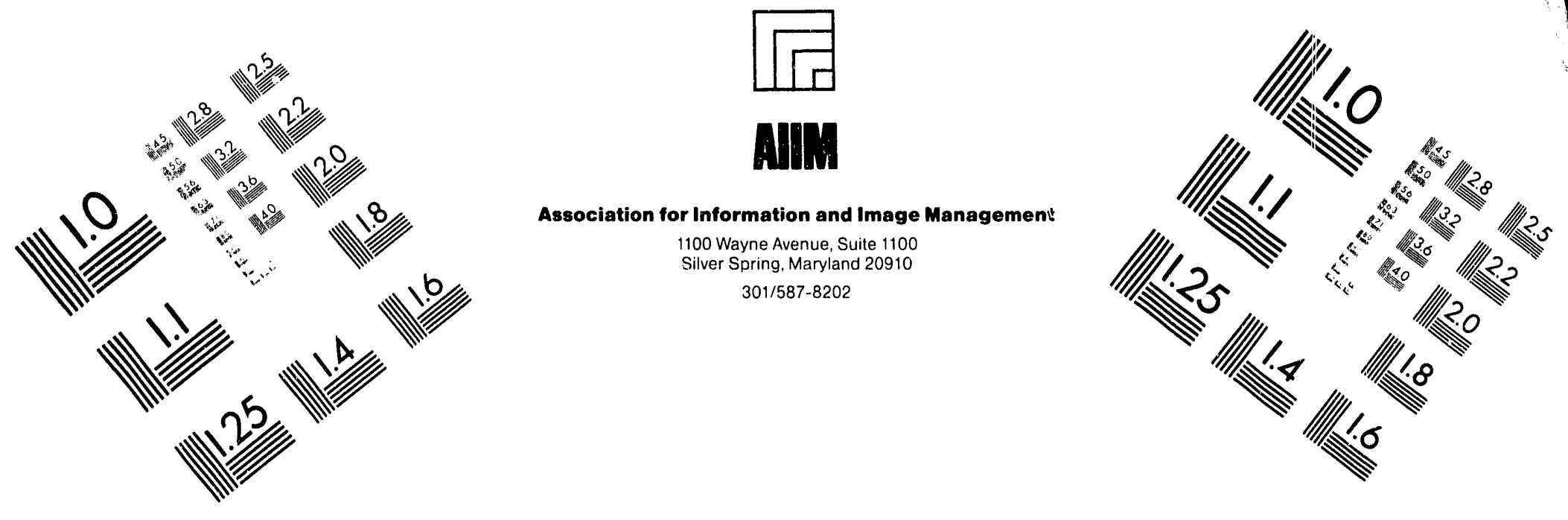

\title{
Centimeter
}

$\begin{array}{llllllllllllllll}1 & 2 & 3 & 4 & 5 & 6 & 7 & 8 & 9 & 10 & 11 & 12 & 13 & 14 & 15 & \mathrm{~mm}\end{array}$

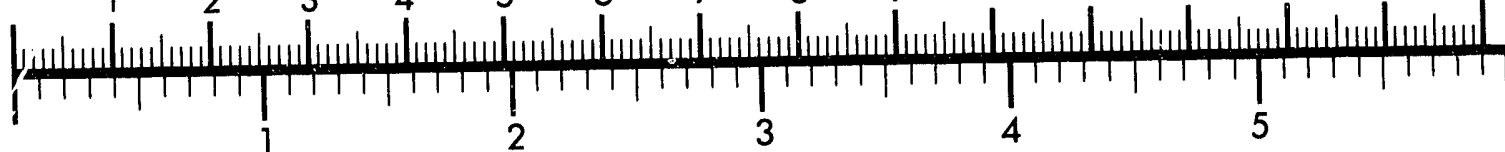
Inches
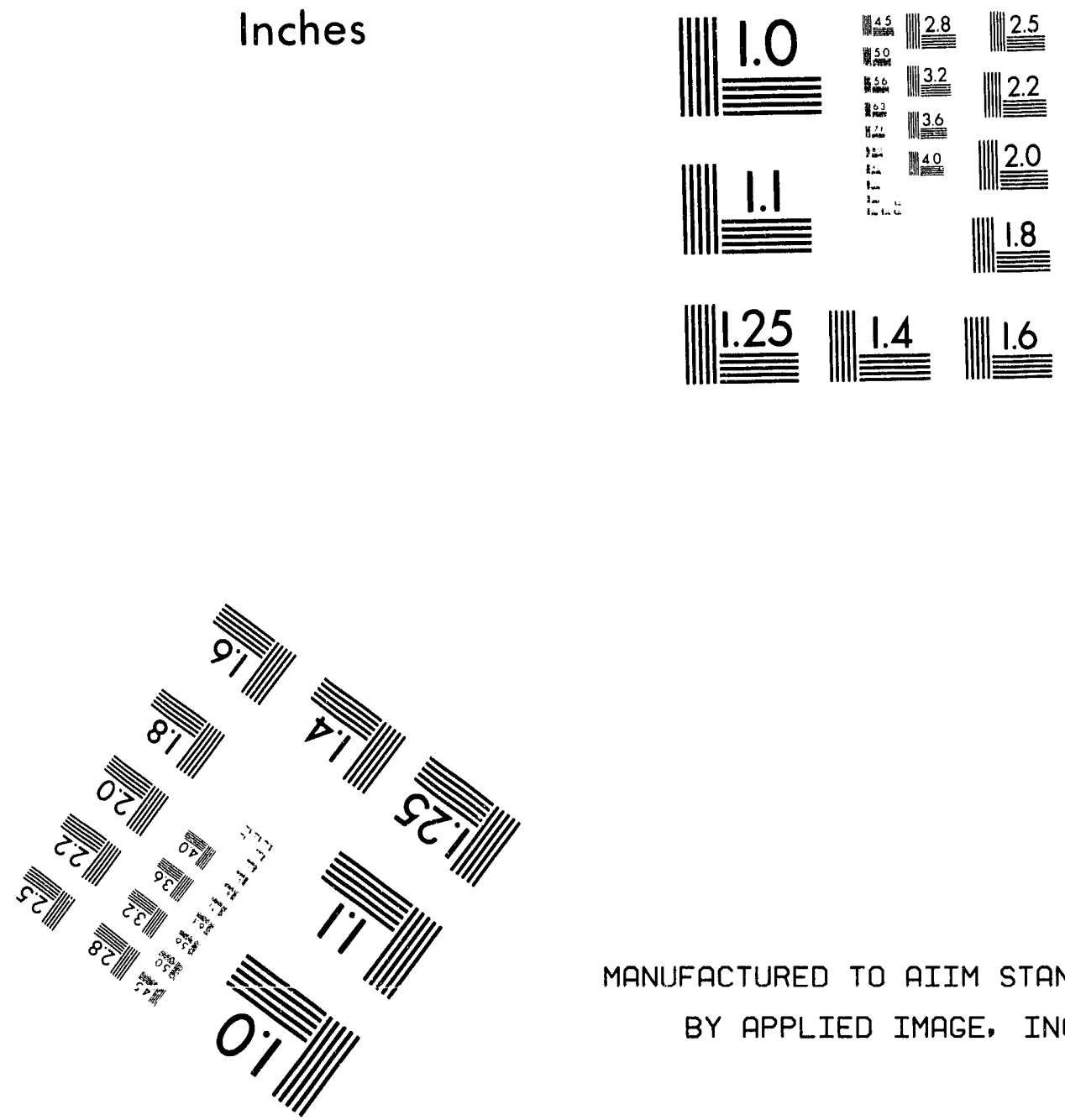

MANUFACTURED TO AIIM STANDARDS

BY APPLIED IMAGE, INC.

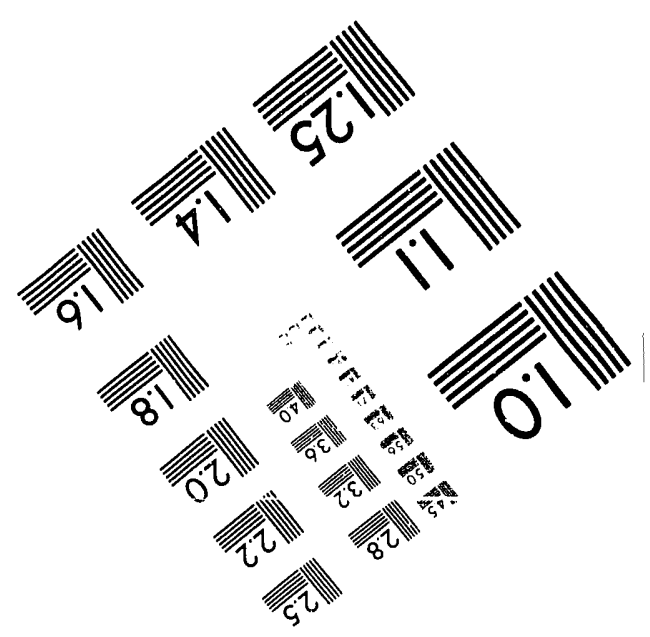



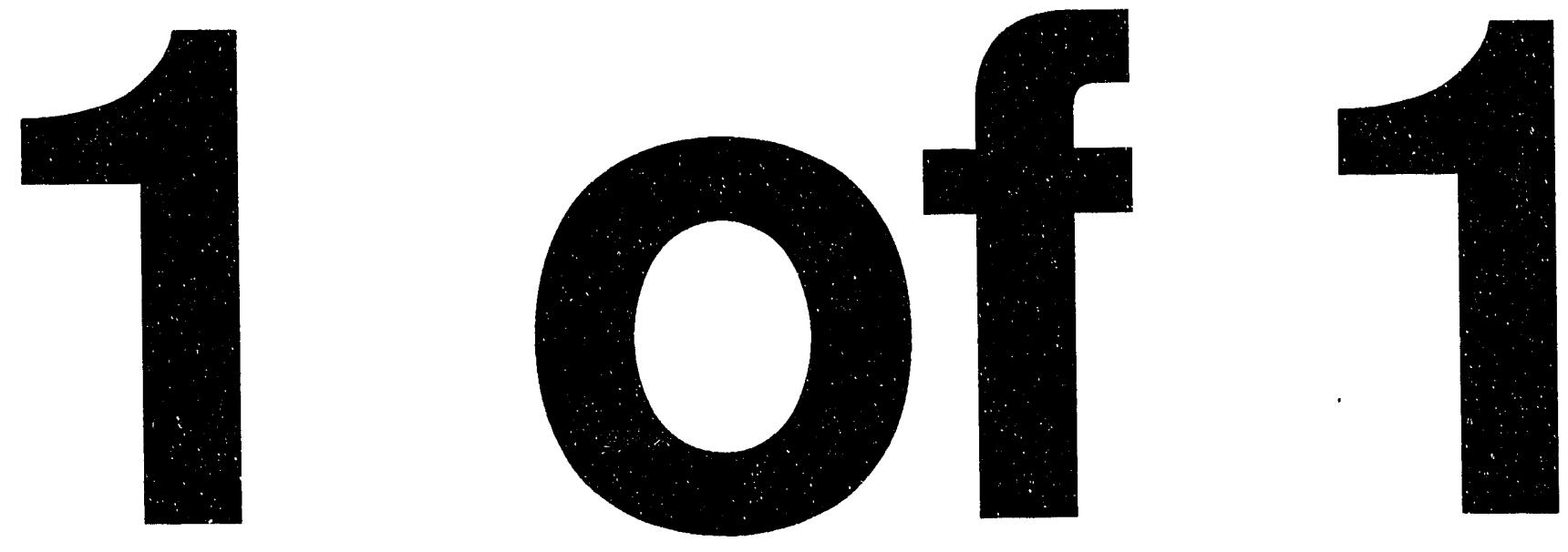


\title{
Test Plan for the Field Evaluation and Demonstration of the Contamination Control Unit
}

\author{
M. R. Winberg \\ D. N. Thompson
}

Published June 1993

\author{
Idaho National Engineering Laboratory \\ EG\&G Idaho, Inc. \\ Idaho Falls, Idaho 83415
}

Prepared for the

U.S. Department of Energy

Office of Environmental Restoration and Waste Management

Idaho Operations Office

Contract DE-AC07-76ID01570

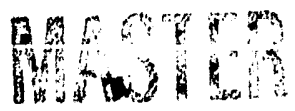




\section{Test Plan for the Field Evaluation and Demonstration of the Contamination Control Unit}

EGG-WTD-10717

Reviewed by

\section{P.N. Pandoleh}

P. D. Randolph, Technical Leader

Radiation Measurements and Development

Approved by

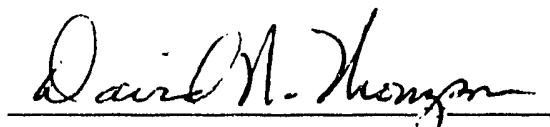

D. N. Thompson, Project Scientist

Science and Technology

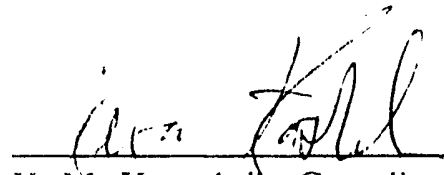

K. M. Kostelnik, Coordinator

Buried Waste Integrated Demonstration

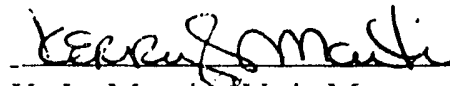

K. L. Martin, Unit Manager

Radiation Measurements and Development

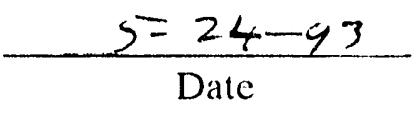

$s=24-93$ Date

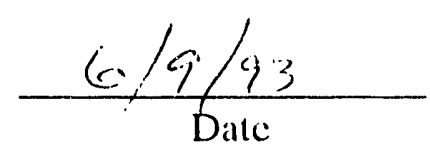

$s=24-93$

Datc 


\begin{abstract}
This report describes test details of a full demonstration of the Contamination Control Unit (CCU). The CCU is a mobile trailer capable of employing the use of soil fixatives, dust suppression agents, misting, and vacuum systems. These systems can perform a large number of contamination control functions to support the Office of Waste Technology Development (OTD) Buried Waste Integrated Demonstration (BWID) projects, transuranic (TRU) waste retrieval operations, and emergency response for hazardous and radioactive materials incidents.

The demonstration will include both performance testing at the North Holmes Laboratory Facility (NHLF) and field testing in conjunction with the Remote Excavation System Demonstration at the Cold Test Pit. The NHLF will test operational parameters using water only, and the field demonstration at the Cold Test Pit involves full scale operation of vacuum, fixant, misting, and dust suppression systems.

Test objectives, detailed experimental procedures, and data quality objectives necessary to perform the field demonstration are included in this test plan.
\end{abstract}




\section{CONTENTS}

ABSTRACT $\ldots \ldots \ldots \ldots \ldots \ldots \ldots \ldots \ldots \ldots \ldots \ldots \ldots \ldots \ldots \ldots \ldots \ldots \ldots \ldots$

ACRONYMS $\ldots \ldots \ldots \ldots \ldots \ldots \ldots \ldots \ldots \ldots \ldots \ldots \ldots \ldots \ldots \ldots \ldots \ldots \ldots$

1. INTRODUCTION $\ldots \ldots \ldots \ldots \ldots \ldots \ldots \ldots \ldots \ldots \ldots \ldots \ldots \ldots \ldots \ldots \ldots$

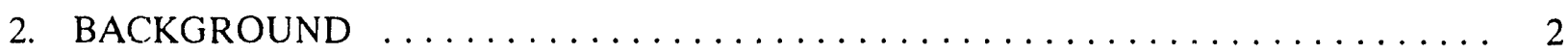

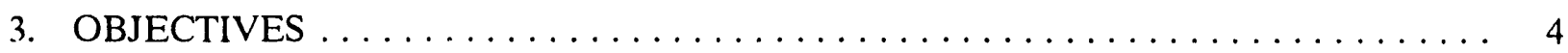

4. ORGANIZATION STRUCTURE $\ldots \ldots \ldots \ldots \ldots \ldots \ldots \ldots \ldots \ldots \ldots \ldots \ldots$

5. DESCRIPTION OF CCU TRAILER AND SYSTEMS $\ldots \ldots \ldots \ldots \ldots \ldots \ldots \ldots$

5.1 Description of the Soil Fixative $(3 \mathrm{M}$ Foam) System $\ldots \ldots \ldots \ldots \ldots \ldots \ldots$

5.2 Description of the Dust Suppression Application System . . . . . . . . . . 8

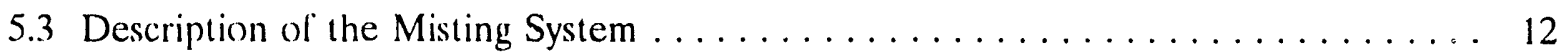

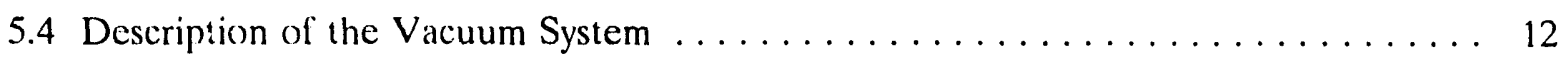

6. PERFORMANCE TESTING OF THE CCU $\ldots \ldots \ldots \ldots \ldots \ldots \ldots \ldots \ldots \ldots$

6.1 Performance Testing of the $3 \mathrm{M}$ Foam System $\ldots \ldots \ldots \ldots \ldots \ldots \ldots \ldots$

6.1.1 Performance Testing of the Dust Suppression Agent System . . . . . . . 20

6.1.2 Performance Testing of the DRYFOG Misting System ............ 22

6.1.3 Performance Testing of the Vacuum System $\ldots \ldots \ldots \ldots \ldots \ldots \ldots \ldots$

6.2 Methods for Supporting the RES Demonstration $\ldots \ldots \ldots \ldots \ldots \ldots \ldots \ldots$

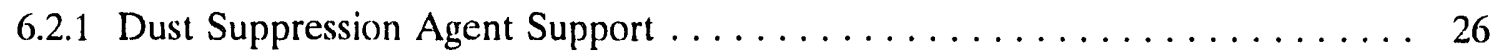

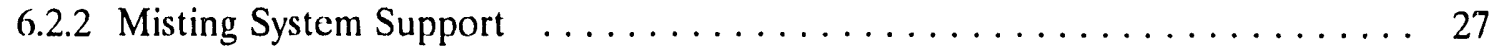

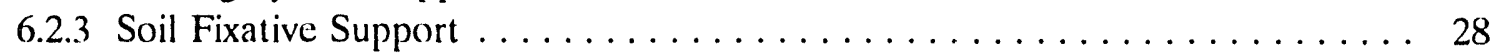

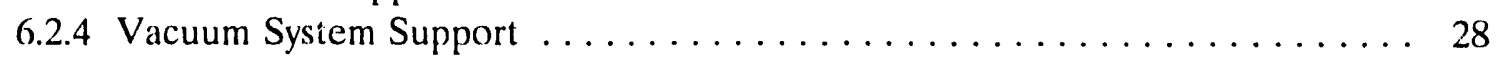

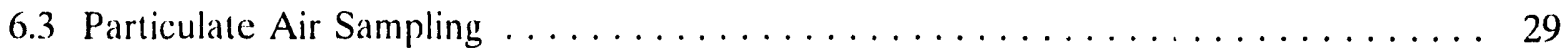

6.3.1 Methods Used to Weigh and Handle Particulate Air Samples . . . . . . . . 31

7. SAMPLE CONTROL AND DOCUMENT MANAGEMENT $\ldots \ldots \ldots \ldots \ldots 2$

8. EQUIPMENT AND SUPPLIES $\ldots \ldots \ldots \ldots \ldots \ldots \ldots \ldots \ldots \ldots \ldots \ldots \ldots$ 
9. SUPPLIES, UTILITIES, AND FACILITIES $\ldots \ldots \ldots \ldots \ldots \ldots \ldots \ldots \ldots \ldots$

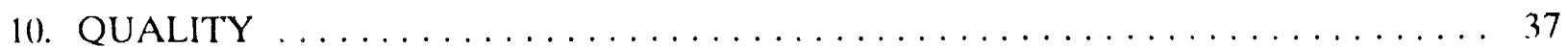

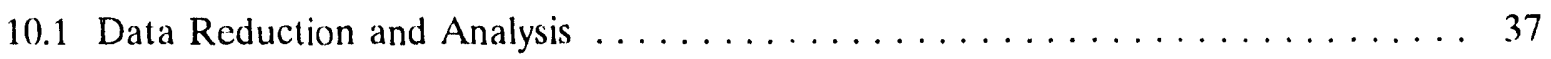

11. SAFETY, TRAINING, AND LOGISTICS $\ldots \ldots \ldots \ldots \ldots \ldots \ldots \ldots \ldots$

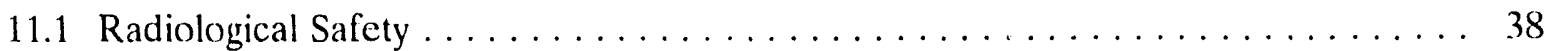

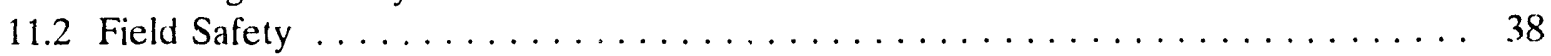

11.3 Waste Management Practices and Training ................. 39

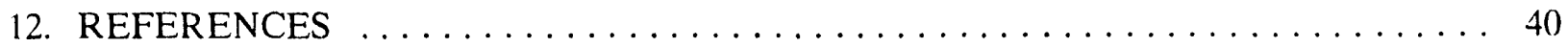

Appendix A-Operating Instructions for Model 70 Stabilized Foam Control Unit . . . . . . . A-1

Appendix B-Vacuum System Model DC5500 $\ldots \ldots \ldots \ldots \ldots \ldots \ldots \ldots \ldots \ldots \ldots$

Appendix C-Calculation Methods $\ldots \ldots \ldots \ldots \ldots \ldots \ldots \ldots \ldots \ldots \ldots \ldots \ldots \ldots \ldots \ldots \ldots$

\section{FIGURES}

1. Organizational structure for the field evaluation and demonstration of the $\mathrm{CCU} . \ldots .7$

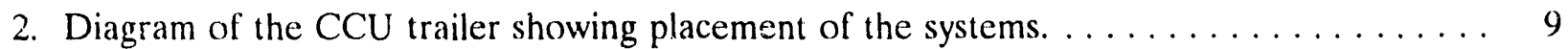

3. Blue box $3 \mathrm{M}$ Foam application system. $\ldots \ldots \ldots \ldots \ldots \ldots \ldots \ldots \ldots \ldots \ldots \ldots$

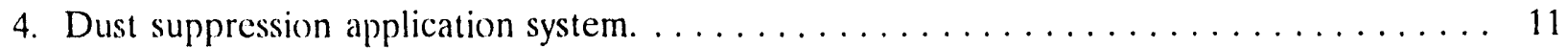

5. Diagram of the misting system. $\ldots \ldots \ldots \ldots \ldots \ldots \ldots \ldots \ldots \ldots \ldots \ldots \ldots \ldots \ldots$

6. Side view of the front face of the Cold Test Pit showing 3M Foam application area. . . 18

7. Sketch showing the cold waste test pit cells and areas for dust suppressant

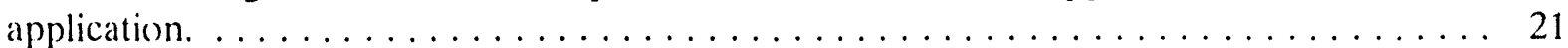

8. Misting system setup for robotic retrieval vehicle demonstration $\ldots \ldots \ldots \ldots \ldots$

9. Diagram of the $47-\mathrm{mm}$ filter sampler. $\ldots \ldots \ldots \ldots \ldots \ldots \ldots \ldots \ldots \ldots \ldots \ldots$ 


\section{ACRONYMS}

$\begin{array}{ll}\text { BWID } & \text { Buried Waste Integrated Demonstration } \\ \text { CCU } & \text { Contamination Control Unit } \\ \text { DOE-ID } & \text { Control frequency } \\ \text { FY } & \text { Fiscal year } \\ \text { HEPA } & \text { High efficiency particulate air } \\ \text { IH } & \text { Industrial hygienist } \\ \text { INEL } & \text { Idaho National Engineering Laboratory } \\ \text { NHLF } & \text { North Holmes Laboratory Facility } \\ \text { OTD } & \text { Office of Waste Technology Development } \\ \text { PPE } & \text { Personal protective equipment } \\ \text { RES } & \text { Remote Excavation System } \\ \text { RM\&D } & \text { Radiation Measurements and Development } \\ \text { RWMC } & \text { Radioactive Waste Management Complex } \\ \text { TRU } & \text { Transuranic } \\ \text { Fiscal year }\end{array}$




\section{Test Plan for the Field Evaluation and Demonstration of the Contamination Control Unit}

\section{INTRODUCTION}

This test plan describes the tests that will be used to perlorm the preliminary evaluation and field demonstration of the Contamination Control Unit (CCU). The CCU is a mobile trailer capable of deploying a soil fixative (3M Foam), dust suppression agents (calcium lignosulfonate and natural polysaccharides), a misting system (DRYFOG Ultrasonic Misting Heads), and a vacuum system (DUSTCONTROL Model DC 5500). These systems are capable of performing a large number of contamination control functions to support the Office of Waste Technology Development (OTD) Buried Waste Integrated Demonstration (BWID) projects, transuranic (TRU) waste retrieval operations and provide an emergency response for hazardous and radioactive materials incidents.

This test plan describes the background of the CCU, objectives of the performance tests, organizational structure for the tesiing, description of the systems to be tested, methods to evaluate the systems, performance objectives of each system, and safety requirements for these evaluations.

The performance tests will be evaluated by independent testing at the NHLF using water only, independent testing at the Cold Test Pit using the actual products intended for the CCU (Flambinder, 3M foam, and polysaccharides), and by supporting the Remote Excavation System (RES) demonstration. Based on these performance tests, an operations manual will be finalized for the CCU.

At the North Holmes Laboratory Facility (NHLF), the CCU systems will be tested with water to determine pressure settings, examine timeframes for dispensing products, verify the functioning of alarms and automatic pump shutoffs, evaluate the application effects of using different product nozzles, and determine leaks in the system.

At the Cold Test Pit, the CCU systems will be tested with actual dust suppression and fixative products to determine the need for "fine tuning" the pressure settings, dispensing timeframes, alarm and pump shutoff timeframes, and nozzle selection effects with each product. Not only will the products be tested and evaluated, but it is also intended that the surrounding traffic areas of the Cold Test Pit be treated as part of these tests.

The primary objective of the CCU testing is to determine its capabilities, applications, and limitations for various project support and emergency response. The secondary objective is to use the knowledge and experience gain to produce an operations manual.

These demonstrations and evaluations are conducted under a technology agreement with BWID originated from the Technical Task Plans ID-121210 and RL-432002 (polysaccharide evaluation). 


\section{BACKGROUND}

During the period fiscal year (FY) 1989 to 1992, the Radiation Measurements and Development (RM\&D) Unit of EG\&G Idaho, Inc. has been involved in research and development of contamination control techniques that could be used in support of retrieval of TRU wastes currently stored at the Radioactive Waste Management Complex (RWMC) at the Idaho National Enginecring Laboratory (INEL). Current plans for the remediation of the RWMC include the retrieval and treatment of over 2 million cubic feet of TRU contaminated wastes, which were shipped to the INEL from weapons fabrication operations at the Rocky Flats Plant. The wastes are currently buried in shallow land filled pits and trenches. Over the years, it is certain that some of the containers have lost their integrity, and the TRU and hazardous materials contaminates have leached into the surrounding soil.

During retrieval operations, it is expected that fugitive dusts will be generated, and the TRU contaminated and/or hazardous materials will become airborne. Because of the high toxicity and low body burdens for TRU and/or hazardous materials, it is important to minimize the generation and spread of lugitive dusts during waste retrieval operations. Initial research involving contamination control included looking for current off-the-shelf systems in use in the mining industry for control of dust generation. Several different products and application systems were identilied, and testing was conducted to evaluate which product and application systems would perform the best on INEL type soils. ${ }^{1.2}$ In 1989, a system was designed to control the generation and spread of contamination during retrieval operations. ${ }^{3}$ This system used containment structures, robotics equipment, rapid monitoring systems, and dust control techniques to provide maximum safety to the environment and personnel during operations. The 1989 to 1991 activities were sponsored by the Buried Waste Program at the INEL. During 1992, work was sponsored by BWID.

During FY-92, design and procurement was initiated to build a single trailer that would serve as a CCU. The purpose of this trailer would be to support BWID demonstration projects that provided dust control capabilities for equipment and retrieval technology evaluations. The trailer will provide contamination control capability for actual retrieval demonstrations and provide an emergency response capability in case of a hazardous or radioactive materials incident. To evaluate the capabilities of the CCU on a large scale, performance testing must be conducted, and an operations manual must be written.

The dust control techniques to be used in the CCU include soil fixatives (chemicals used to trap contaminants between the soil surface and the air for nontraftic areas) used on digface areas to control the exposed areas of a digface, dust suppression agents (chemicals or natural agents used to minimize contamination spread in high traffic areas) used on vehicle traffic surfaces, misting systems to control dusts during digging and dumping operations, and vacuum systems to decontaminate equipment and hot spot areas. During FY-92, the final selection of products and application systems was made and is described below.

- The 3M Foam with the Williams Model 80 foam generating system was chosen as a soil fixative.

- Flambinder (calcium lignosulfonate) with a premixed tank and spray system was chosen as a dust suppression agent. 
- Natural polysaccharides (sugar beet mono and polysaccharides and potato starch) was also selerted as a dust suppression agent that will be used in the Flambinder premixed tank and spray system.

- DRYFOG Ultrasonic Misting System, manufactured by SONICS Inc., wass chosen as a misting system.

- DUSTCONTROL Model DC 550) nuclear grade vacuum system, manufictured by Transmatic Corporation, was chosen as the vacuum system. 


\section{OBJECTIVES}

The CCU will be tested for operational facility and effectiveness during the robotics retrieval demonstration in June 1993. The June 1993 demonstration has the following objectives:

1. In full scale, evaluate the capability of the dust control products to control the spread of dust during the RES demonstration. This will be assessed by performing retrieval with and without application of the vacuum and dust control products. During these tests, air particulate samples will be obtained with high and low volume air samplers and by comparing filter weights.

2. Evaluate the reliability of the CCU to dispense the products without clogging the nozzle, plugging the vacuum lines, or causing other major failures. Reliability will be evaluated after each product application.

3. Evaluate the capability to dispense dust control products and vacuum in an actual field application. The capability will be evaluated by forcing all vacuum and dispensing hoses through the entire range of motion expected during remediation activities. A successful demonstration show that the apparatus can perform in the RWMC environment without major equipment failure during demonstrations 2 week period. For example, the hoses will be operated in fully and partially extended positions. The CCU will be deemed operationally ready if the results of the air sampling from the field demonstration show that each of the products used in a near, full-scale demonstration perform within a specific range. This range was identified from earlier studies on dust control. ${ }^{2,3,4}$ These studies showed that each of the products employed by the CCU had a dust control efficiency under laboratory controlled conditions of between 75 to $95 \%$ dust control. The CCU will be considered operationally ready if using these products in conjunction with the dust suppression agents applied to vehicle traffic areas, misting systems employed over digging and or dumping areas, and soil fixatives applied to the retrieval areas, a minimum dust control efficiency of $75 \%$ or greater can be obtained in the containment enclosure when compared to conditions with no contamination control techniques in use.

4. Evaluate the compatibility of the CCU operation with other retrieval equipment such as the excavator and cameras used to control the vehicle. This will be qualitatively evaluated by observing operational difficulties caused by using dust control products and quantitatively by keeping a record of the relative humidity to see if the misting system affects the relative humidity.

In addition to the preceding major objectives, the following qualitative objectives will be examined.

5. Evaluate the ability of the soil fixatives, 3M Foam and natural polysaccharides (potato starch), to be used effectively and compatibly with other necessary retricval operations.

6. Evaluate the product performance and mean time to failure for each system application of the CCU. 
7. Make recommendations for design or equipment modifications based on the qualitative methods.

8. Perform an initial ficld evaluation of the ability to apply immobilization materials and the range of application using each of the systems installed in the CCU. This will determine if the systems perform according to the specifications as detailed in this document.

9. Evaluate the dust control efficiency of the natural polysaccharides to immobilize surface contamination or suppress airborne contamination.

10. Evaluate the extent, if any, that additional waste is generated.

To meet the above objectives, data quality will be verified using peer review by the RM\&D technical leader (who is knowledgeable of the data, assumptions methodology, and measurements analysis) to verify that the data are within the performance specifications as detailed in this test plan. The following accuracy specifications apply:

1. Flow measurements shall be within $\pm 10 \%$. Ten percent was chosen because the vendor calibration data suggest that this is achievable.

2. Mass measurements shall be within $\pm 0.0001 \mathrm{~g}$.

3. Total volume of product used on a test area will be estimated within \pm 10 gal. Ten gallons was chosen because it is an easily observable quantity relative to the tank size containing the product.

4. Total area covered by the products will be estimated within $\pm 2 \mathrm{yd}^{2}$. Two square yards was chosen because of the nature in controlling the product from the spray nozzles. 


\section{ORGANIZATION STRUCTURE}

Figure 1 shows the organizational structure for the tests to be performed as described in this test plan. The funding organization for this test is the DOE OTD. EG\&G Idaho's Waste Technology Development Group has direct funding through Waste Technology Development to evaluate and demonstrate waste management and retrieval technologies for application to current DOE environmental restoration programs. The following people have these responsibilities in this project:

- DOE Headquarters Program Manager-Provides overall headquarter cognizance of BWID programs.

- U.S. Department of Energy Idaho Operations Office (DOE-ID) Program Manager-Provides overall DOE-ID cognizance of BWID activities.

- BWID Coordinator-Responsible for coordinating the technology demonstration programs.

- DOE Management and Operations (M\&O) Contract Manager-EG\&G Idaho management representative.

- BWID Test Coordinator-Responsible for performance of all specific tasks in the project. Defines and write statements of work, procures vendor services, tracks, and maintains project budgets and progress. Provides field technical support. Writes and publishes final report.

- Project Manager-Responsible for overall performance of work to be conducted in the project. Maintains and tracks project funding and provides technical direction and expertise.

- Project Scientist-Provides scientific and technical support. Writes sampling and test plans for performance for project tasks. Has the authority to change a procedure during or after a test as long as the test objectives are not compromised. Provides data analysis and interpretation. Assists work package manager in preparation of final report.

- $\quad$ Field Sampling Personnel-Collects data and samples in the field for analysis. The lield team leader prepares and collects materials, data, and samples in the field. Procures sampling and analysis services and equipment. Provides technical direction and support to field sampling personnel. Has the authority to change a procedure during or after a test as long as the test objectives are not compromised. 


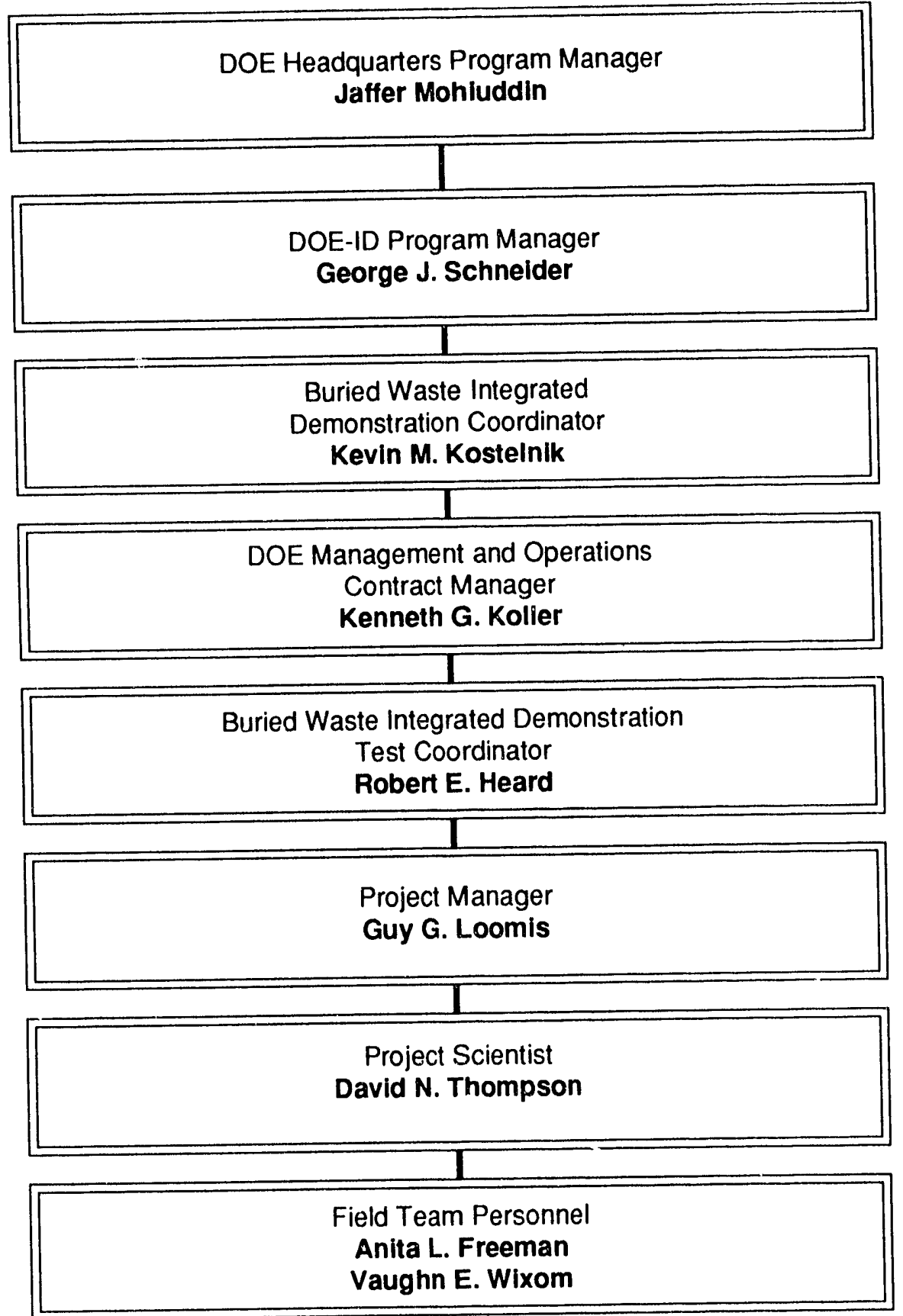

B93 0063

Figure 1. Organizational structure for the field evaluation and demonstration of the CCU. 


\section{DESCRIPTION OF CCU TRAILER AND SYSTEMS}

The CCU consists of a $9 \mathrm{ft}$ wide $\times 24 \mathrm{ft}$ long enclosed trailer manufactured by Wells Cargo Company of Salt Lake City, Utah. The trailer is dual axle with a standard $25 / 16$ in. ball hitch. A diagram of the trailer showing the placement of the systems is shown in Figure 2. The trailer contains the application systems for $3 \mathrm{M}$ Foam, natural polysaccharides, Flambinder, DRYFOG misting, and vacuuming. The systems are arranged in the trailer to allow access for maintenance and service via the sets of double doors (two sets on each side). The large rear doors allow access to the hose reels and main control panel. The hose reels contain the hoses, each of which is at least $100 \mathrm{ft}$ long, and nozzles for each system. The control panel will allow the operator to control cach system and operate the hose reels. The trailer requires access to a $480 \mathrm{~V}$ power supply either from a building hookup or portable $50 \mathrm{~kW}$ generator. Operation of the trailer requires two or three people depending on which system is being used. The following sections will describe each of the individual systems.

\subsection{Description of the Soil Fixative (3M Foam) System}

The 3M Foam system utilizes a two-part chemical mixing apparatus to mix a long-term vapor suppressing foam. The chemical constituents will be procured from the $3 \mathrm{M}$ Company. The system will use the 3M FX-9161 Foam Stabilizer and 3M FX-9162 Foam Concentrate.

The product is mixed and applied using the Model $703 \mathrm{M}$ Foam application system manufactured by Williams Fire \& Hazardous Control Inc. This system and the product were tested to satisfaction during FY-92. A set of operating instructions from the manufacturer is included in Appendix A of this test plan. The Model 70 or "Blue Box" foam application system is specially designed to mix water, FX-9162 foam concentrate, and FX-9161 foam stabilizer in the proper proportions (6\% 9161, 6\% 9162, and $88 \%$ water) to create a foam material that is dispensed using volume expansion nozzles. The mixed foam will create a vapor suppressing membrane capable of lasting for several months. The blue box system is shown in a diagram on Figure 3.

The blue box is a hand-carried unit that is placed outside, near the area to be sprayed. The feed waler connections are then made between the blue box and water supply. The discharge hose is connected 10 the blue box and the aeration and the discharge nozzle is placed on the discharge end of the hose. The maximum length of the discharge hose is $100 \mathrm{ft}$ based on the current water pressures to the blue box. For the applications stated in this test plan, the discharge hose will be approximately 20 ft long. The foam concentrate and foam stabilizer lines are placed in their respective pails. The unit is then ready to operate. The system must be purged after each use to prevent the material from solidilying in the blue box, discharge line, and nozzle. The mixed foam begins to cure immediately and will set up within 30 to 90 seconds. When the unir is shut down, it must be purged according to the procedures in the operations manual.

\subsection{Description of the Dust Suppression Application System}

The dust suppression application system is the most versatile system contained on the CCU. The system consists of a tank to hold the premixed product, a pump, and an application hose and spray nozzle. A diagram of the system is shown on Figure 4 . The system is versatile because any 


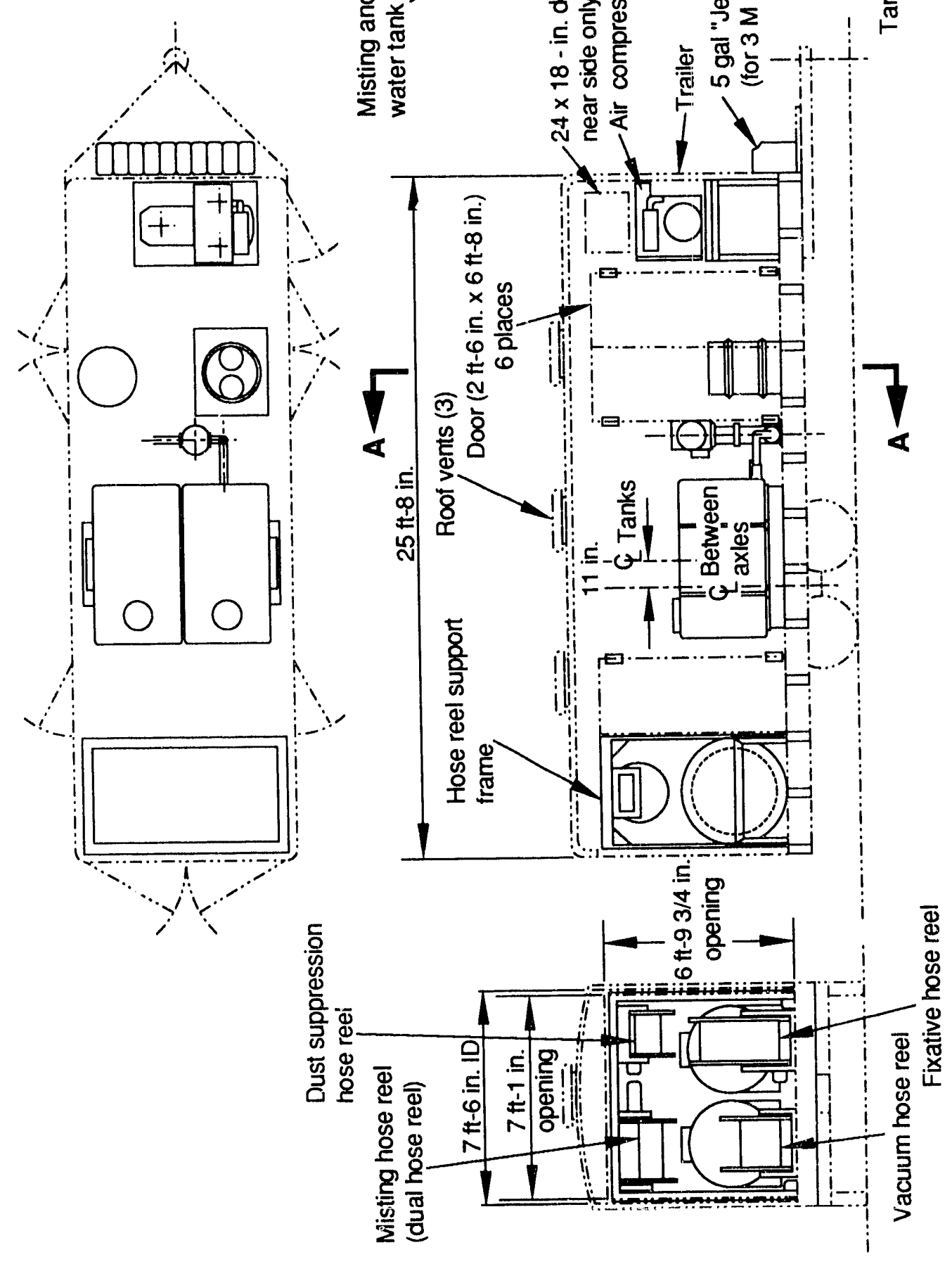

4
4

I0
8
8
8

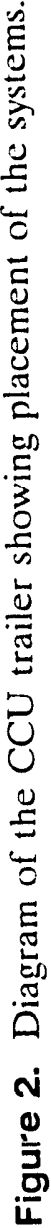




\section{CONTAMINATION CONTROL UNIT}

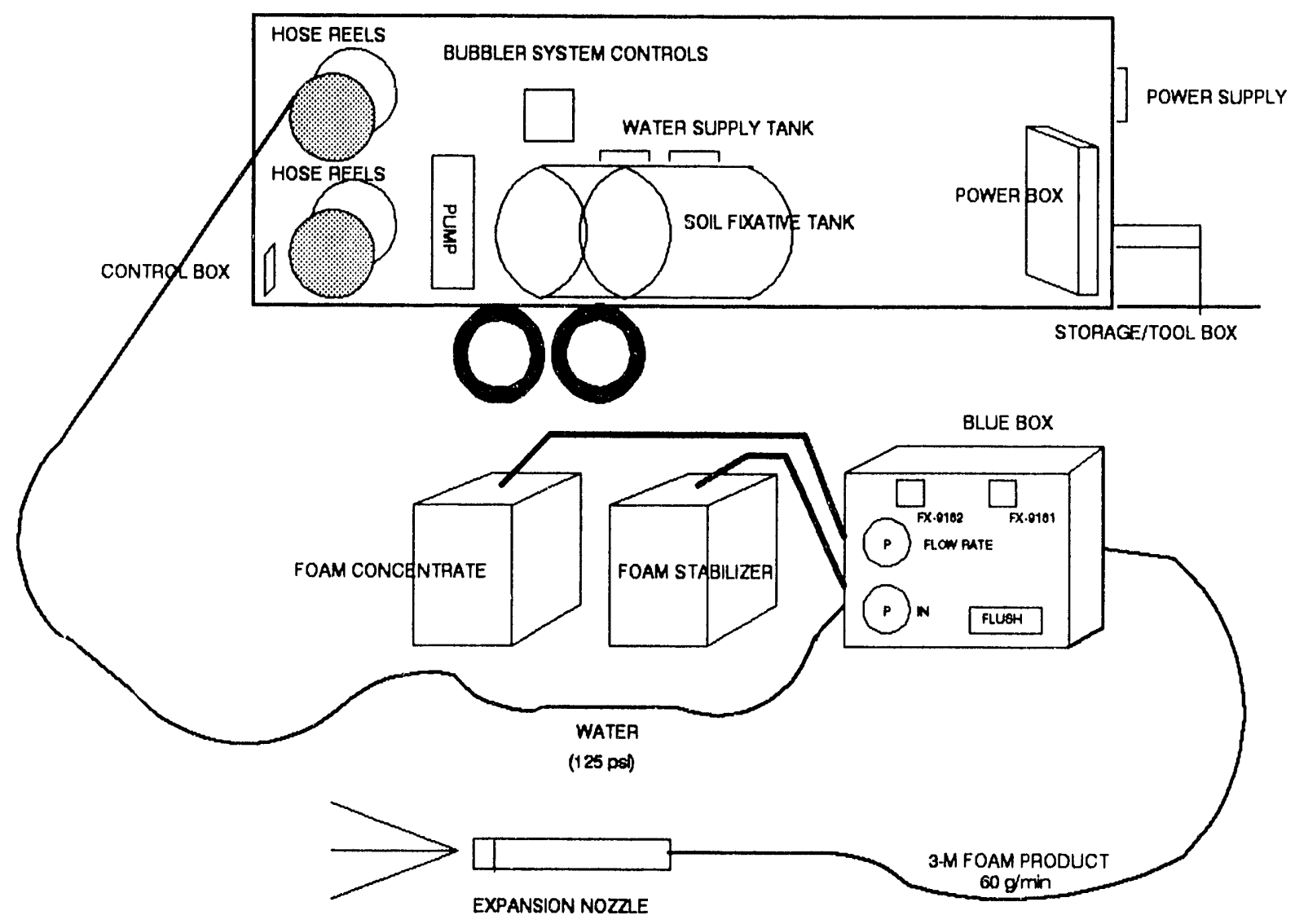

Figure 3. Blue box 3M Foam application system. 


\section{CONTAMINATION CONTROL UNIT}

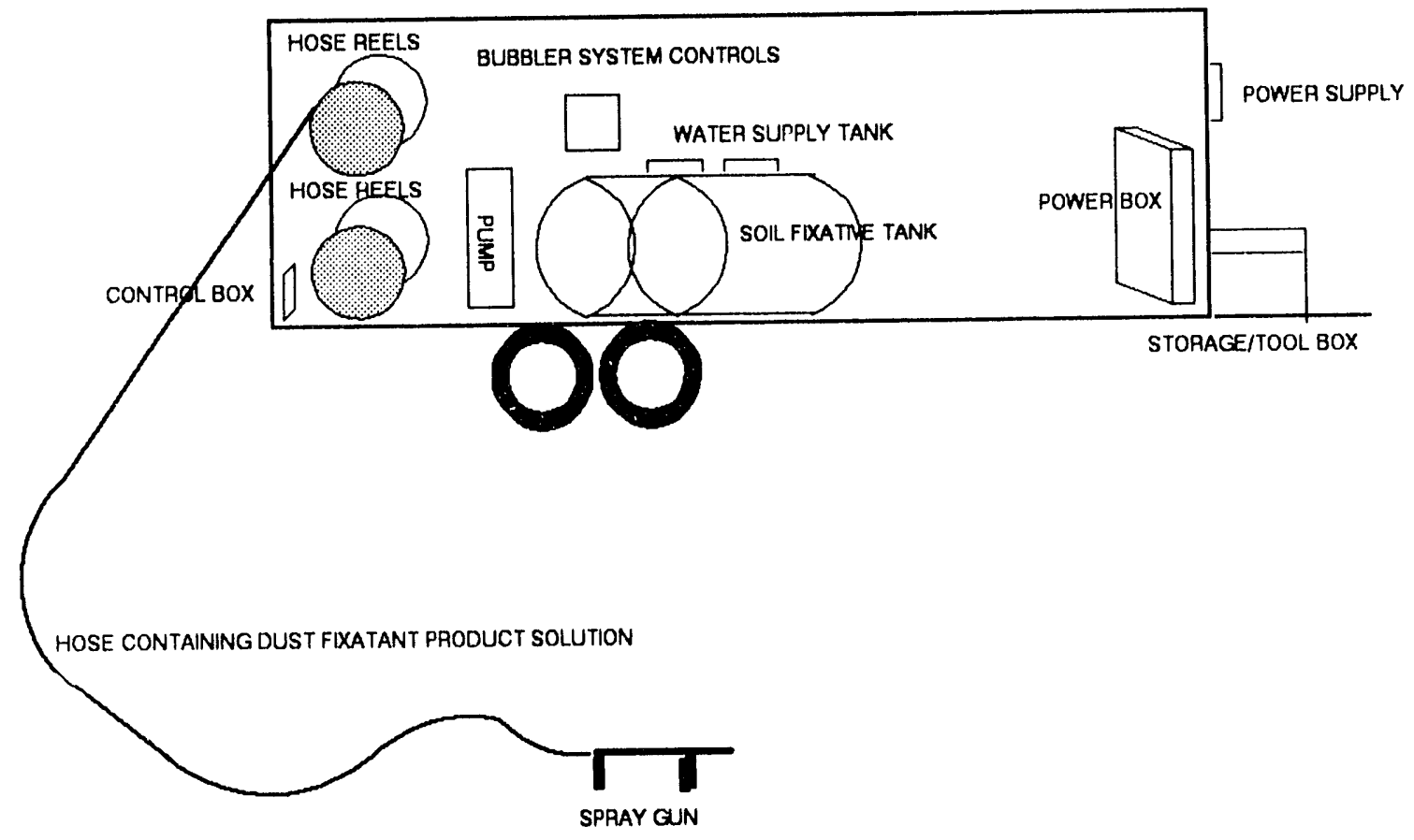

Figure 4. Dust suppression application system. 
type of dust suppressant that requires mixing with water is capable of being employed by this system. Previous studies conducted at the INEL evaluated several dust suppressants for application in the CCU. ${ }^{2}$ The dust suppressant chosen was Flambinder (a calcium lignosulfonate) because of its ability to work well on INEL soils and its environmental acceptability. Natural polysaccharides from sugar beets and potato starch have also been selected for testing in this system. The polysaccharides from sugar beets will be used for vehicular traffic areas as a dust suppressant and compared to the calcium lignosulfonate, while the potato starch will be used as a soil fixative in the excavation pit and compared to the fixative, $3 \mathrm{M}$ Foam.

The system is operated by premixing the product in the designated tank. The application hose with its attached nozzle is payed out from the hose reel to the application area, and the pump is turned on. The product is applied as needed. When application is completed, the pump is turned off, and the hose is payed back into the hose reel. The are no clogging or set up problems associated with calcium lignosulfonate; however, it is recommended that any residual product in the tank not be allowed to dry. Detailed procedures to be used to test this system will be described in subsequent sections.

\subsection{Description of the Misting System}

The DRYFOG Ultrasonic Misting System utilizes a specially designed nozzle to mix air and water to create a fine cone of mist. The misting heads require a clean water supply with particulate (extraneous material such as vegetation or dirt accidentally entering the tank or the formation of hard water deposits) removed down to $50 \mu$ when functioning at their full capability. A diagram of the misting system is shown in Figure 5. The CCU contains a 300)-gal tank for a water supply, compressor to supply air to the misting system, and pump to provide water pressure at the misting heads. The trailer is designed to operate up to six heads either individually or in any combination. It is expected that four misting heads and stands will be used for the demonstration operations. Each misting head will be attachud to a 1 or $6-\mathrm{ft}$ stand, depending on the control application, placed in strategic positions (without interlering with other local activities) to provide contamination control for digging and dumping operations. The air and water lines from the misting heads are connected to a spray manifold the junction where the air and water from the trailer pass through a valve and regulator then go to the misting head(s)]. The operator then turns the heads off and on at the manifold, as needed. When misting operations are completed, the air and water lines can be disconnecled from the spray manilold and the supply lines payed back in to the hose reel.

\subsection{Description of the Vacuum System}

The vacuum system in the $\mathrm{CCU}$ is a nuclear grade, high efficiency particulate air (HEPA) filtered system. The vacuum system, Model DC 550() , is a $5-7.5 \mathrm{~kW}$, two stage system manufactured by Transmatic, Inc. The manufacturer's description and specifications are found in Appendix B of this test plan. The vacuum system provides a means to rapidly decontaminate equipment, personnel, and work areas.

The vacuum system is capable of removing loose particulate debris ranging from small particles micron size up to large debris $1.5 \mathrm{in}$. in diameter. Heavy items such as rocks will be limited (o) approximately $3 / 4$ in. so that the denser material will still be able to flow from the nozzle to the 


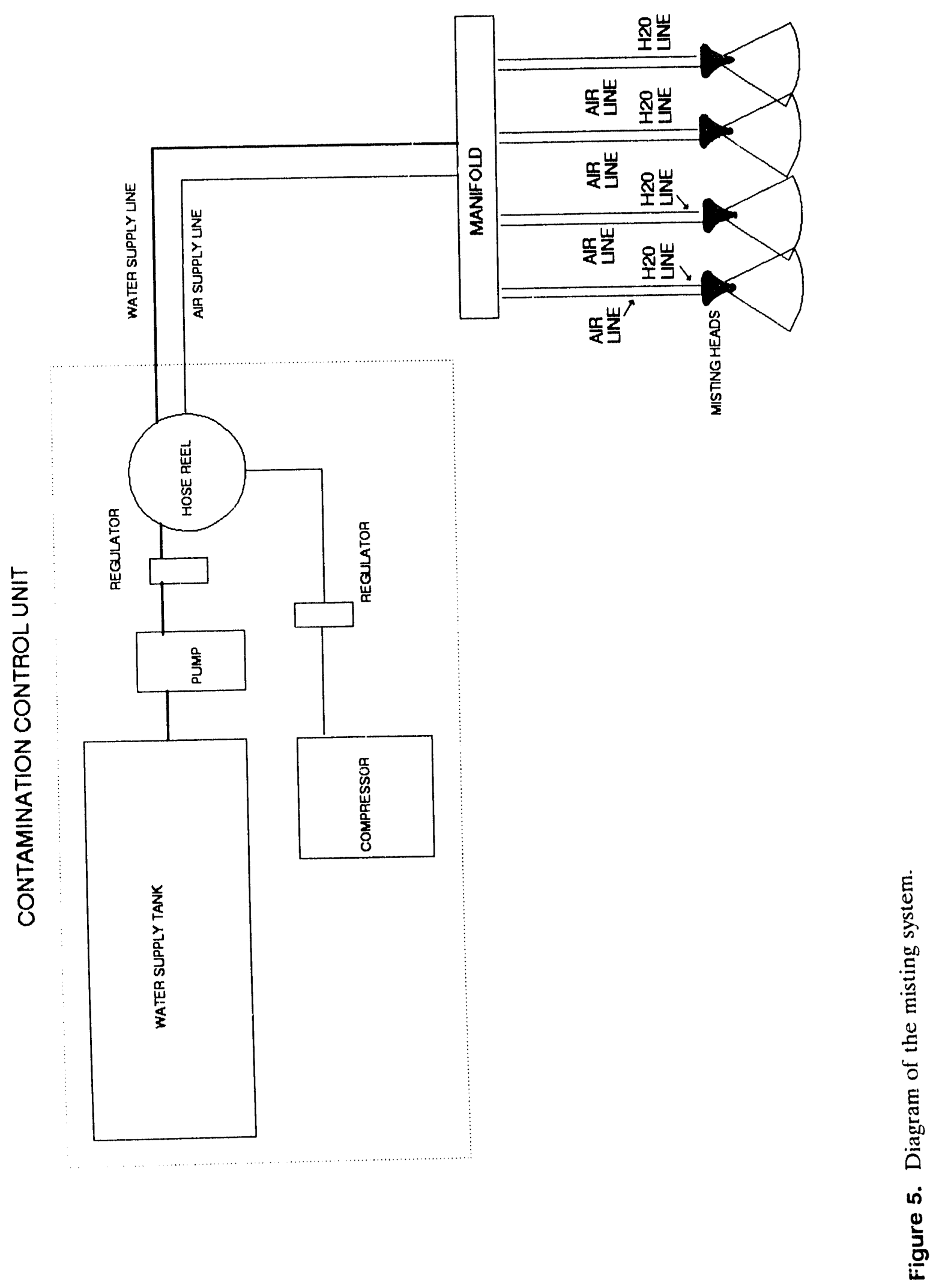


debris container without lodging in the hose line. The system includes a HEPA filter and 55-gal debris container. The container can be changed out when full and replaced with any standard 55-gal drum. The full drum can then be properly sealed for final disposal. Because of the limited space in the CCU trailer, moving a full drum will be difficult. It is anticipated that the drum will be replaced while it is still maneuverable (however, this goes against waste minimization principles), or the hose from the vacuum to the drum will be extended so that the debris drum can be placed outside of the trailer on a pallet. There is no mechanism to determine the amount of dust and debris deposited into the drum other than by checking the weight of the drum.

The system is operated by turning it off and on as needed. The vacuum hose can be payed in or out from its hose reel located at the rear of the trailer. Attachments may be used on the hose as needed to complete the job. Additional information for testing the vacuum system will be discussed in later sections of this test plan. 


\section{PERFORMANCE TESTING OF THE CCU}

This section of the test plan outlines the methods used to test the capabilities of the CCU. The testing of the $\mathrm{CCU}$ will take place in two stages:

- Stage 1-Performance testing at the NHLF to test the operational parameters for each system using water only, make any needed system modifications, and collect information necessary to write an operations manual for the CCU.

- $\quad$ Stage 2-Ficild demonstration of the CCU in support of the RES demonstration conducted at the Cold Test Pit by BWID during the summer of FY-93.

Because of the location of the NHLF, it will not be possible to test the CCU systems with actual product after the water tests have been completed. It is mandatory that the initial testing with water be done at the NHLF because the engineers and technicians who designed and installed the CCU equipment are located at the NHLF and are readily available for modifications and any necessary repairs.

The Stage 1 tests will be performed with water only in the 3M Foam system and ciust suppression system. The misting system and vacuum system will be tested as designed. The purpose of these tests is to check the operability and installation integrity of each of the systems. Because the $C C U$ is a prototype, its reliability will be determined through repeated operation. Each individual system in the CCU has its own life expectancy based on the specifications provided by the different manufacturers, so it is difficult to estimate the number of hours of operation needed to evaluate the reliability of the CCU. After the completion of Stage 1 , the $\mathrm{CCU}$ is expected to be reliable throughout the testing and support operations for the demonstrations mentioned in this test plan.

Modifications will be made as recommended by the project scientist and engineers to maximize the operational characteristics. Operational characteristics will be maximized by adjusting pressure levels to the hoses, changing different nozzles in the soil fixative and dust suppression systems, and adjusting water to air ratios in the misting system, which will provide the best dust suppression capability and contamination control.

In the CCU, there are several gauges and sensors to indicate proper operational paramelers. The gauges for water pressure and air pressure will be optimized, adjustable settings locked in place, and gauge readings written into the CCU logbook. The blue box has two pressure gauges for inlet and outlet water pressures. These have been calibrated and set by the manufacturer specifically for the use of $3 \mathrm{M}$ Foam and stabilizer and will not be adjusted.

There is a bubbler system incorporated into the CCU that indicales the water levels in each of the 300-gal tanks. The bubbler system has sensors that will cause an audible alarm when the water drops to a critical level. This critical level is established so that enough water remains in the soil fixative tank to flush or purge the hoses from the blue box to the nozzle. This seiting will be approximated in Stage 1 testing of the soil fixative system and fine tuned in Stage 2. The bubbler system also has a sensor to automatically shut off the operating pump from either 30()-gal tank when the water level nears empty (to prevent the pumps from pumping air and damaging the pumps). This sensor will be set in Stage 1 testing. 
In the CCU logbook, records will be maintained of the number of failures, time between failures, downtimes, costs for repairs, equipment needed for repair, and power costs. Performance success will also be noted. Based on this information, operating and purchase costs can be estimated for the $\mathrm{CCU}$ for the operations described in this test plan. If appropriate, this information will be included in the final report.

Stage 2 will address objectives 2, 5, 6, 7, 8, and 9 listed in the Section 3 of this document. Stage 2 will be a full field test of each of the systems using the actual application products at the Cold Test Pit. The purpose of the Stage 2 tests is to evaluate each of the systems in an operational environment, determine the best operational parameters for each system (i.e., pressures, flows, mixing, etc.), and acquire experience and knowledge for developing a CCU operations manual. The first draft of the operations manual will then be used during the RES field demonstration support phase of the testing. The field demonstraiion support phase should fill in any gaps in the draft operations manual so that the final manual can be written after the demonstrations. Details for the field evaluation of each of the systems will be explained in the following sections of this test plan.

There is no required or particular sequence of activities for the systems in the CCU, but there is a sequence of activities (procedures) to operate each system. The systems can be operated in any order and that order is based on the requirements of the project or task.

\subsection{Performance Testing of the 3M Foam System}

The Stage 1 performance testing of the $3 \mathrm{M}$ Foam system will be performed (using water) in the rear parking lot of the NHLF. These tests will be performed without product mixed into the system. The trailer will be placed outside, and power will be connected to the generator. The following steps vill be performed:

1. Fill the foam system supply tank with water (approximately $300 \mathrm{gal}$ ) and connect all hoses to the blue box.

2. Start the pump and turn on the system. Note the start time of the pump in the project logbook.

3. Note the inlet and outlet pressure on the blue box in the project logbook at 1 minute intervals and ensure that they stay within the operational parameters noted in Appendix A of this test plan.

4. During operations, inspect all hoses and supply lines to ensure that there are no leaks. If leaks are present, stop the test and fix the leaks. Repeat test again.

5. Note in the project logbook the total water used at 1 minute intervals and total amount of time it takes to empty the tank.

6. Make any modifications as directed by the project scientist and engineer to bring the system to the manufacturer's specifications. 
7. Note the pay-out and pay-in capabilities of the hose reel, which will be evaluated to determine the requirements for using the system hoses.

Stage 2 for testing the 3M Foam system will be conducted at the Cold Test Pit located near the RWMC after the CCU has been moved from NHLF. A generator and water truck will also need to be available. The trailer will be set up and connected to the power supply at the gencrator. The foam system feedwater tank will then be filled (approximately $300 \mathrm{gal}$ ). The blue box will be connected to the feed water supply, and the discharge hose will be connected to a nozzle. The operator will then obtain two pails each of the FX-9161 and FX-9162 foam concentrate and foam stabilizer and set them adjacent to the blue box. The feed hoses for the FX-9161 and 9162 will be placed in the appropriate pails. The system will then be ready to test. The $3 \mathrm{M}$ Foam system will require three people for operation: control panel operator, blue box operator, and spray nozzle operator. The responsibilities of each operator are

- The Control Panel Operator stands at the rear doors of the trailer and operates the control panel. The control panel operates the supply water feed pump and hose reels, and monitors the feed tank water level.

- The Blue Box Operator stands at the blue box that is positioned near the spray area. The operator is responsible for ensuring that all hose connections to the blue box are made properly, monitoring the gauges on the blue box during operation to ensure that the unit is functioning properly, changing the feed hoses for the FX-9161 and 9162 foam concentrate and stabilizer as needed from empty pails to fuil pails, and putting the blue box into the purge mode on signal from the spray nozzle operator when application is complete or from the control panel operator when the supply tank level is low.

- The Spray Nozzle Operator holds the expansion nozzle and directs the foam onto that application area. This operator is responsible for informing the blue box operator that application is complete so that the blue box can be put into the purge mode.

The following tests will be performed by the above operators:

- Test 1 determines the total amount of time and water will be needed to purge the system. The necessary information for setting the audible alarm sensor for the proper water level of the supply tank will be provided.

The 3M Foam system will be turned on and operated according to the test procedures detailed in Appendix A of this test plan.

The control panel operator will note the start time and the time that foam begins to spray from the nozzle in the project logbook. The blue box operator will verify that the pressure indicators on the blue box are within the manufacturer's specifications. During this time, the nozzle will be directed onto the front exposed face of the Cold Test Pit (sce Figure 6) by the spray nozzle operator. 


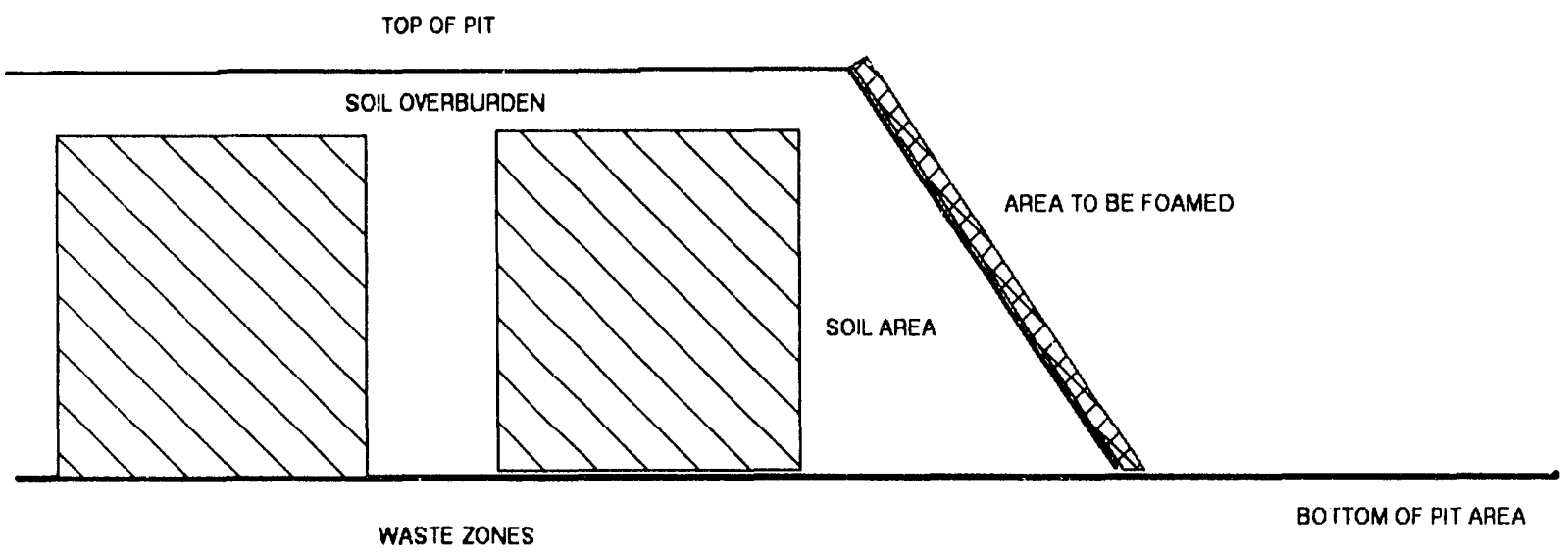

SIDE VIEW OF FRONT FACE OF CTP SHOWING 3M FOAM APPLICATION AREA

Figure 6. Side view of the front face of the Cold Test Pit showing $3 \mathrm{M}$ Foam application area. 
Once foam is spraying from the nozzle, the control panel operator will note the tank level and time and inform the blue box operator using hand signals, a two-way radio, or by shouting to put the foam system into the purge mode.

The control panel operator will note the total time and water used to purge the system. A lcvel mark will then be placed on the supply tank that will be easily seen from the control panel at 1.5 times the amourit of water needed to purge the system to allow for a satety margin. When the water reaches the level mark, the $3 \mathrm{M}$ Foam system must be placeid in the purge mode to clean the system before the water runs out. At no time must the $3 \mathrm{M}$ Foam system be shut down without purging the blue box hoses and discharge hose. If thisystem is not purged, foan will set up in the blue box and discharge line and cause permanent damage.

- Test 2 determines the operational parameters on a single tank (i.e., total square feet foam coverage, foam stabilizer and concentrate usage, average depth, operation time before purging, etc.).

The $3 M$ Foam systeni will be set up as in Test 1 with the 300 -gal water tank full and $3 \mathrm{M}$ Foam anc' stäbilizer (FX-9161 and FX-9162) available and ready for use (several 5-gal pails are opened and standing by).

When the $3 \mathrm{M}$ Foam system has been turned on, the control panel operator will note the on-time in the proiect lugbook. The spray operator will direct the foam over the premarked application area covering the area with foam at an average 1 -in. depth (as suggesteo by the manuíacturer for the best curing thickness), or until the control operator notes tha' the minimum purge level of the supply tank is reached. Because the control panel operator has more time availatie, he/she will note the time taken to reach this level and tell the blue box operator to place the blue box in the purge mode. As soon as the unit has purged. the system will be shut down.

The application area will be measured and evaluated to determine the total area covered, average depth of coverage, and foam characteristics (cure times, consistency, etc.). The control panel operator will note any pertinent information regarding system operation that they know will be needed for the final operations manual.

The foamed area will be allowed to cure to a firm consistency $(30$ to 60 minutes $)$. The equipment operator will then come in with the loader and attempt to dig into the face and load the soil into a dump truck to evaluate the breakaway characteristics to the foam. If the project scientist determines that additional tests need to be performed to fully evaluate the system, fresh soil will be brought to the digface, and Test 2 will be modilied and/or repeated. The BWID test coordinator at the Cold Test Pii will be notified for concurrence.

If the project scientist realizes that a procedure or process is incorrect or fails, work will stup. The problem will be evaluated, the procedure changed, and the task repeated. 
During all phases of these tests, photographs and video tape will be taken to ensure a complete projeci racord and allow the project scientist and staff to review and evaluate the system performance. All pe itinent data and experience will be used to write the $3 \mathrm{M}$ Foam Applications System section of the operations manual. After this phase of testing is complete, the CCU will be brought back to the NHLF for any modifications that may be needed.

\subsubsection{Performance Testing of the Dust Suppression Agent System}

Stage 1 of the performance testing of the dust suppression agent system will be performed at the parking lot of the NHLF. These tests will be performed without any product placed in the supply tank. Water only will be used for these tests. These tests will evaluate the overall performance of the system, ensure that the system functions according to specifications, and make any modifications to the system to maximize the performance. The dust suppression agent system will be evaluated during Stage 1 as follows:

1. The CCU will be moved out onto the parking lot of the NHLF and the power connections made.

2. The system will be activated by turning on the feedwater supply tank pump and inspected for any leaks. All leaks will be repaired.

3. The system performance characteristics will be evaluated (i.e., line pressures, regulator settings, flow rates, etc.)

4. Any repairs or modifications will be made in preparation for the Stage 2 testing.

Stage 2, field evaluation testing of the dust suppressant system in the CCU will take place at the Cold Test Pit. A dust suppressant application area will be designated as shown in Figure 7. The dust suppressants to be tested will be Flambinder (calcium lignosulfonate) and the natural sugar beet polysaccharide, XDCA. Flambinder was the chosen dust suppressant because of its superiority and advantages over other tested suppressants. Since Flambinder works best on premoistened soil, the area will be sprayed with water at a rate of $1 \mathrm{gal} / \mathrm{yd}^{2}$ before application of the product. ${ }^{2}$ The dust suppression system will require a control panel operator and spray nozzle operator. The responsibilities of these operators are

- The Control Panel Iperator stands at the rear doors of the trailer and operates the control panel. The control panel operates the supply water feed pump and hose reels and monitors the feed tank water level.

- The Spray Nozzle Operator holds the spray nozzle and directs the dust suppression agent onto the application area.

Stage 2 testing of the dust suppression agents Flambinder and XDCA will be performed on the application area as follows.

1. The spray nozzle operator will begin to coat the premoistened application area with product at the rate of $1 \mathrm{gal} / \mathrm{yd}^{2}$. The spray nozzle operator and control panel operator will 


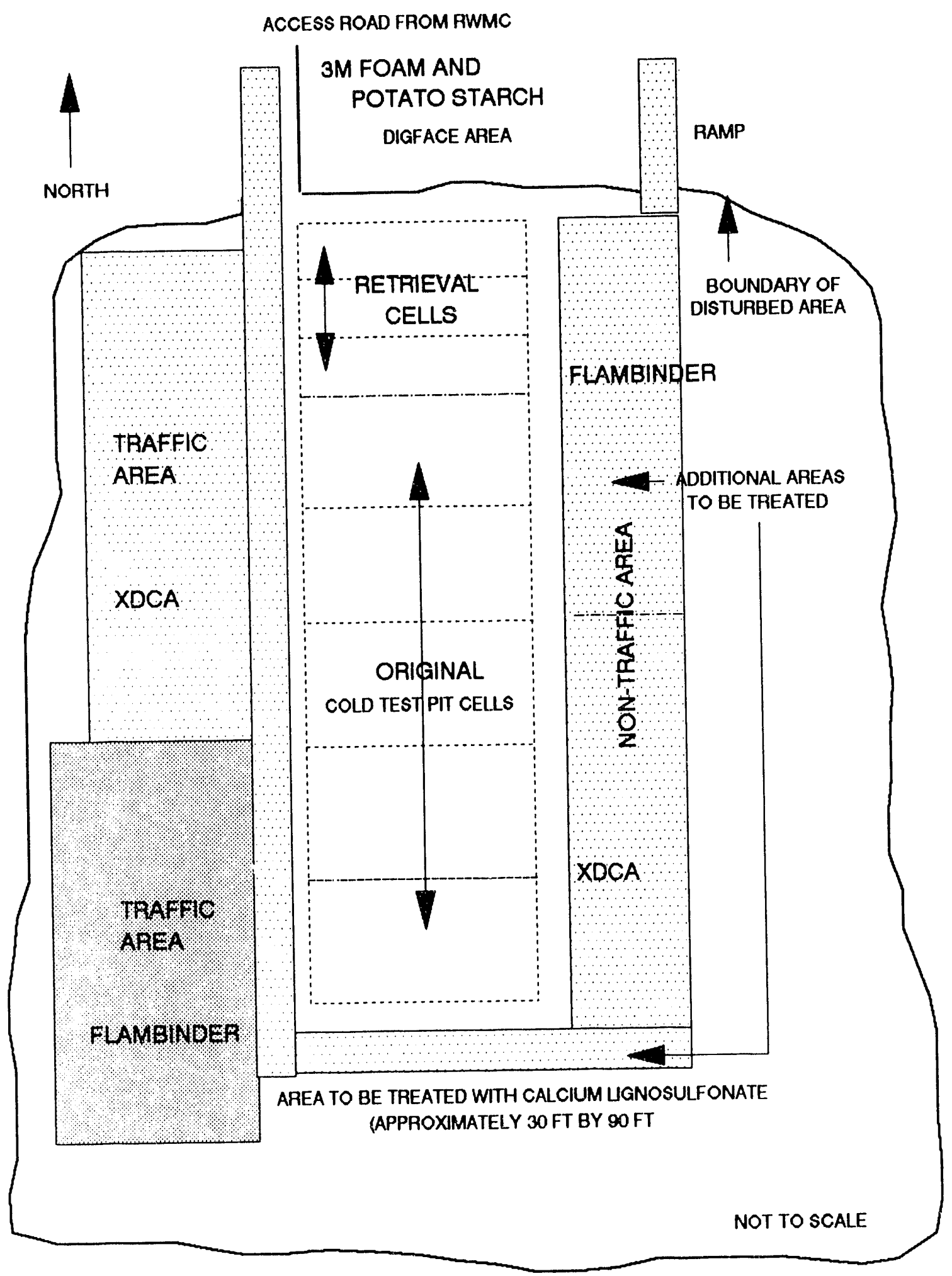

Figure 7. Sketch showing the cold waste test pit cells and areas for dust suppressant application. 
maintain communication (via head set radios) about the tank level, spray rate, and areas covered to ensure proper application.

2. When the application area is covered, the control panel operator will turn off the pump and note the time and volume of the supply tank used in the logbook.

3. The product on the application area will be allowed to cure, and the cure time will be noted in the logbook. Other factors to be noted in the logbook are the air temperature, weather conditions, and wind speed and direction.

4. When the supply tank is empty or when all applications of a particular product are completed, the supply tank will be tilled with water, rinsed, and the rinse water will be purged from the system.

5. If the project scientist realizes that a procedure or process is incorrect or fails, work will stop. The problem will be evaluated, the procedure changed, and the task repeated.

After this initial test is complete, other areas of the Cold Test Pit such as the access roads and parking areas may be treated with Flambinder and XDCA to provide additional operational experience and provide dust control for the vehicle traffic surfaces in preparation for the demonstration projects to be conducted during the summer of FY-93.

During all phases of these tests, photographs and video tape will be taken to ensure a complete project record and allow the project scientist and staff to review and evaluate the system performance. All pertinent data and experience will be used to write the Dust Suppression Applications System section of the operations manual. After all tests of the CCU systems are complete, the CCU will be brought back to the NHLF for any modifications that may be needed.

\subsubsection{Performance Testing of the DRYFOG Misting System}

The DRYFOG misting system will be evaluated at the parking area of the NHLF. No testing of this system will be necessary at the Cold Test Pit until the RES demonstration begins. These tests will be explained in a later section of this test plan. The field test at the NHLF will consist of operating the system at the NHLF to ensure that the unit functions according to manufacturer's specifications. The misting system can be operated from the controls at the control panel or from the ball valves at the manifold / the manifold is the junction where the air and water from the trailer each pass through a valve and regulator then go to the misting head(s)]. The control pancl operator has the same responsibilities as in previous sections. The testing sequence for the misting system will be as follows:

1. The control pancl operator will start the compressor and leedwater pump to start the air and water flow to the nozzles. The control panel operator will note the time and tank level at the start of the test.

2. While operating, the system will be checked for leaks and proper operating flows and pressures. All pressure and tlow adjustments will be noted in the logbook. Il any leaks are present, they will be fixed, and the test repeated. 
3. The misting system will be operated for 10 minutes where the water level in the supply tank will be checked in 1 minute intervals.

4. After 10 minutes, the system will be turned off, and the total water volume used will be noted in the project logbook.

5. Any modifications recommended by the project scientist will then be made, and the lest repeated to determine performance changes.

6. If the project scientist realizes that a procedure or process is incorrect or lails, work will stop. The problem will be evaluated, the procedure changed, and the task repeated.

During all phases of these tests, photographs and video tape will be taken to ensure a complete project record and allow the project scientist and staff to review and evaluate the system performance. All pertinent data and experience will be used to write the Misting Application System section of the operations manual.

\subsubsection{Performance Testing of the Vacuum System}

The vacuum system will be tested in two stages. Stage 1 will be an initial evaluation at the NHLF; Stage 2 will take place at the Cold Test Pit. The vacuum system will require a control panel operator and vacuum hose operator. The responsibilities of these operators are

- The Control Panel Operator turns the vacuum system on and off and monitor the level of the catch drum.

- The Vacuum Hose Operator uses the vacuum hose and attachments to perform the decontamination operations as required.

The Stage 1 testing at the NHLF will test the basic performance characteristics of the vacuum system and determine if any modifications are needed before moving the CCU to the field for additional testing. The following tests will be performed:

1. A $2 \times 4-f t$ test area will be covered with a mixture of different types of debris, such as small rocks and pebbles, soil, small paper scrap or packaging materials, etc.

2. The control panel operator will turn on the system, and the vacuum hose operator will attempt to remove all the materials from the test area. The vacuum hose operator will note if any material or debris was difficult or unable to be removed from the test area. The observation will be noted in the project logbook.

3. The vacuum system will be turned off, and the debris canister removed and emptied.

4. If the project scientist realizes that a procedure or process is incorrect or fails, work will stop. The problem will be evaluated, the procedure changed, and the task repeated. 
The original design of the vacuum system proposed having the debris canister reside in the trailer. After further thought and discussion, it will actually be positioned outside the trailer on a pallet. Two potential problems could oceur that make this change necessary: lirst, the canister or drum could become too heavy to move for disposal with the drum mover (when lull, the drum could weigh up to $500 \mathrm{lbs}$.), and second, if the vacuum system is treating actual contaminated soil or debris, the vacuum system will become contaminated from the end of the hose (or attachment) to the HEPA filter located in the vacuum housing. The largest part of the problem is removing the lid to the debris canister. This will have to be done outside of the trailer in a zoned area (probably using a glove box or bag). Attempts to remove the canister lid inside the trailer could cause contamination spread throughout the trailer. It is expected that the hose will be contaminated to a certain degree, and a determination will be made for removing the hose for disposal or decontamination. The vacuum motor and housing are protected hy the HEPA filter at the inlet of the vacuum housing.

During all phases of these tests, photographs and video tape will be taken to ensure a complete project record and allow the project scientist and staff to review and evaluate the system performance. All pertinent datia and experience will be used to write the Vacuum System section of the operations manual.

Upon completion of performance tests of the CCU systems, the operations manual will be written for the CCU and its systems. This manual will be used to operate the system in support of the BWID demonstrations, contamination control during RWMC operations, and emergency response.

\subsection{Methods for Supporting the RES Demonstration}

The CCU will be used to support the RES demonstration that will be conducted by BWID during the summer of FY-93. This demonstration will test and evaluate the operational characteristics of a robotic, remote-controlled excavation vehicle. As part of this demonstration, the CCU will be used to provide contamination control services in a noncontaminated environment. The purpose for providing this service is to test the CCU in an operational mode that may be found in an actual retricval operation. Objectives 1, 3, 4, and 10 from Section 3 will be addressed in this document.

The RES demonstration will be conducted inside an 8()$\times 8()$-ft tent to simulate a real retrieval elfort and minimize weather effects. The CCU will be tested using the dust suppression agents on vehicle traffic surfaces and misting system and soil fixative system over the excavation and dumping areas (see Figure 8). Air particulate samplers will be used to measure the particulate dust ecincentration around each pit where these products and/or systems will be employed. The samplers will be placed as close to each pit as possible without interfering with the misting heads or excavation vehicle. Filter samples will be taken with and without the CCU systems or products employed to evaluate the relative performance of these systems in a full scale operation. The test methods for the RES demonstration will be addressed in a separate test plan. ${ }^{5}$ The robotic vehicle will be lested in $(w 0)$ phases:

- Phase 1: Overburden removal using the robotic vehicke to remove the 2 to 4 fit of soil overburden over the new retrieval eell added to the Cold Test Pit in FY-9?. 


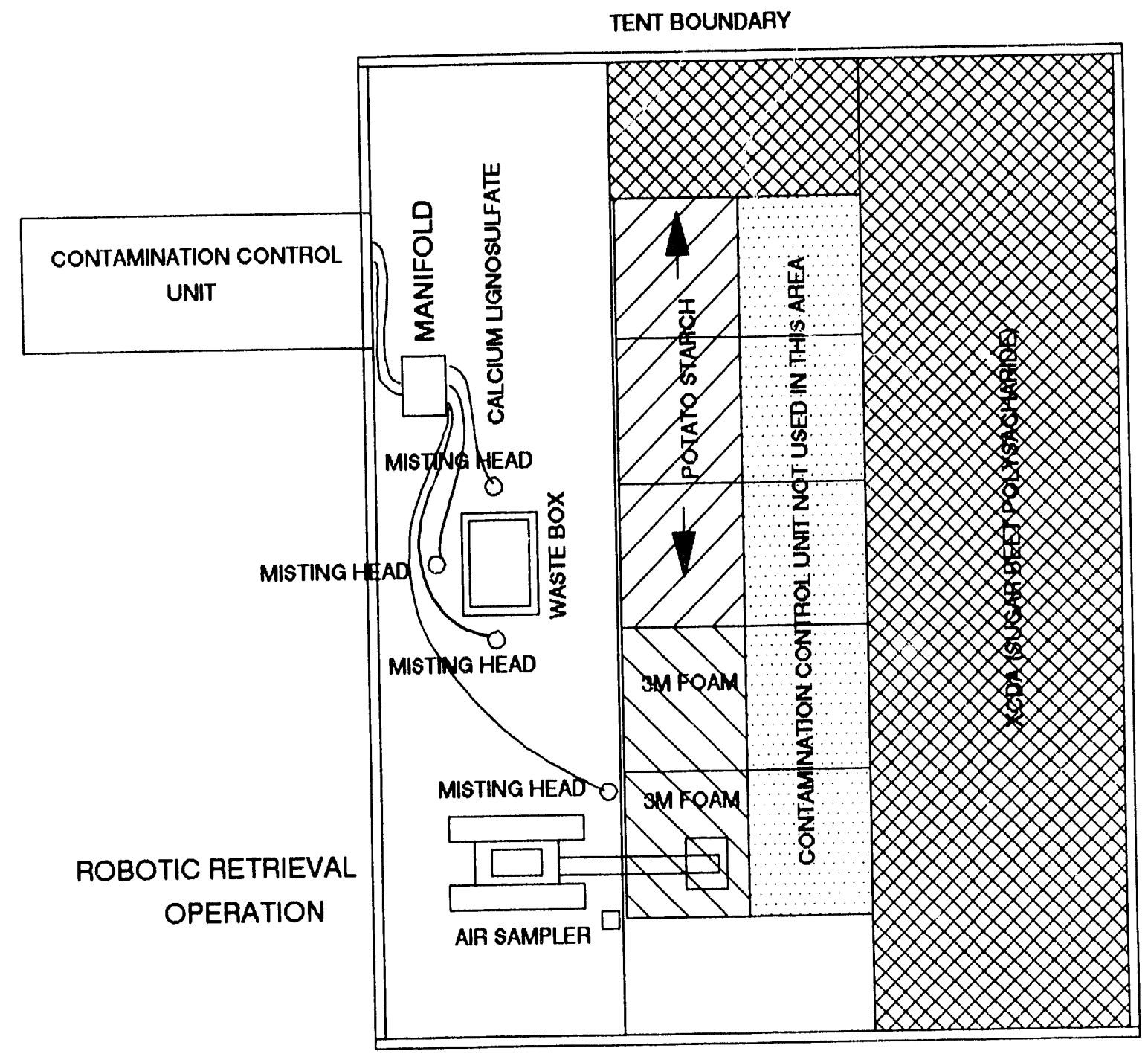

Figure 8. Misting system setup for robotic retrieval vehicle demonstration. 
- Phase 2: Waste retrieval using the robotic vehicle to remove soil and waste from the waste zone.

The following sections of this test plan will detail the methods that will be used to provide the support to Phase 2, RES demonstration.

The retrieval cell of the Cold Test Pit is divided into four waste zones. Each waste zone will be divided in half, one half with contamination control support and one half without support. Air particulate samplers $(47 \mathrm{~mm})$ will be positioned around the waste zone as close as possible to the zone boundary. Because of space restrictions between the excavator and zone boundary, the number of samplers that can be put around each zone (as many as 10) will be limited. Alter the overburden is removed, the excavation vehicle will be positioned over the first waste zone, and retrieval operations will begin on the first half of the zone where no contamination control support will be provided. After the first half of a waste zone has been cleared, the vehicle will be positioned over the next half zone. Contamination control support will be established using $3 \mathrm{M}$ Foam or potato starch on the digface and using the misting system during the excavation and dumping opcration.

\subsubsection{Dust Suppression Agent Support}

The dust suppression agent Flambinder (calcium lignosulfonate) and XDCA (sugar beet polysaccharides) will be applied to all vehicle traffic surfaces in the test area before any equipment staging and project operations. The primary benefit of using the dust suppression agent (o) the RES demonstration is 10 minimize the background airborne dust concentration in the work area caused by vehicle traffic and wind. By using this product on vehicle traffic surfaces and around the general work area, visibility will be improved, and there will be less airborne dust to clog or affect air samplers, equipment, and electronics. Dust concentrations measured by the air samplers should reflect dust generated from the digging and dumping operations, and the background dust concentration should be minimized. Potential traffic and work areas to be treated are shown in Figure 7. Most of these areas will have had an initial treatment during the field evaluation of the CCU. Since most of the treated areas will be outside of a containment structure, the basis for evaluation will be to observe and note the integrity of the calcium lignosulfonate and polysaccharide during operations in the project logbook. The following details should be noted in the project logbook:

- Status of the treated areas and differences as noted from the time of initial application during the field evaluation to the beginning of the RES demonstration

- Locations of any areas where reapplication of the product may be needed as determined by the project scientist (with BWID test coordinator concurrence) and the amount of produc! reapplied, weather conditions, and curing times for the reapplied product.

- Relative amount of traffic over the treated areas during the demonstration and amount of calcium lignosulfonate and/or polysaccharides applied to the heavy tratfic areas. Weather conditions (i.c., temperature, wind speed, direction, and humidity) and curing limes at the time of reapplication will also be noted. 
- Date, time, and amounts of any precipitation received during the demonstration and its effects on the treated area.

- General performance and functionality of the application system. Detcrmine any further modifications that could be made to enhance system performance.

It will be the responsibility of the project scientist to determine where, when, and how much product will be applied or reapplied during the demonstration. These decisions will be made based upon past experience with this product and the operational requirements of the project. The BWID test coordinator will be notified for concurrence.

6.2.1.1 Use of Polysaccharides as a Dust Suppression Agent. The use of Flambinder as a dust suppression agent during the excavation demonstration will be supplemented by the use of XDCA (a sugar beet polysaccharide) in selected areas. The use of polysaccharides will be in support of a Westinghouse Hantord work package sponsored by BWID. The XDCA will be applied in the same type of traffic areas as Flambinder using the same dispensing system in the CCU to compare product performance. Possible areas of application for polysaccharides is shown on Figure 7. The qualitative data that includes time of application, time of observation, coverage, conditions, and product performance will be documented using the same methods described for Flambinder and the data provided to Westinghouse Hanford for their final report.

\subsubsection{Misting System Support}

The misting system will be used in conjunction with the $3 \mathrm{M}$ Foain and potato starch to control fugitive dust generation over the excavation and dumping area. It will be cvaluated using $47-\mathrm{mm}$ air particulate samplers placed adjacent to the digging and dumping area, where there is no interference with the misting heads/spray or excavation operations.

A series of digging operations will be performed on the first half of the first waste zone without misting or foam to establish a baseline air dust concentration. The sampler filters will be collected after the waste zone is cleared of waste but before the excavator moves to the next half of the zone.

When the first half of the waste zone is excavated, another series of digging operations will then be performed with the misting system and foam system (or potato starch system) in operation. The sampling positions must be duplicated as closely as possible over each waste zonc. Fresh filters will be placed back into the sampler holders before the excavation begins. The particulate filters will be collected after the excavation operation and the results compared to the baseline concentration. Comparisons of dust mass will determine a dust control factor and a dust control efficiency for the tests in this operation. The results of these tests will be used to determine the elfectiveness of using low volume misting in a large scale excavation and retrieval operation.

The project scientist or lield team leader may reconfigure the misting head locations to maximize the system performance. Misting operations will be performed over each of the waste zones to gain operation knowledge and experience using the system on a large scale operation. The misting system will be operated using the instructions found in the operations manual for the CCU. The misting system will be turned on only while operations are being performed and turned off when completed. 
Eflorts must be made to mimic or to repeat the same number and types of operations performed during the series of digging operations.

All pertinent events, operational changes, and observations will be noted in the logbook for further reference.

\subsubsection{Soil Fixative Support}

The soil fixative, $3 \mathrm{M}$ Foam, will be used on the digging arcas before digging begins and after a waste zone has been cleared to fix and stabilize the digface surfaces to reduce the movements of soil or generation of dust from those surfaces. The $3 \mathrm{M}$ Foam application system on the CCU will be used to provide this capability. The general method for foam application will be

1. After the first half of the first waste zone has been excavated, the $3 \mathrm{M}$ Foam will be applied to the remaining dig area of the waste zone. This area will be covered with a 1-in. layer of foam to ensure proper coverage. When the foam is properly applied, the $3 \mathrm{M}$ system will be purged with water. When the water begins to flow from the nozzle instead of foam, the system will be shut off. The foam will cure for 5 to 10 minutes before digging operations begin with the misting system running. The foam will be reapplied as more and more untreated soil becomes exposed. This will be a judgement call by the ficld team leader and will be based on excess dust emission from the excavation operation or when the entire surface is exposed with untreated soil.

2. At the end of the work day, as a new area of waste is exposed within a zonc, or after a waste zone is cleared; all exposed areas will be covered with a 1 -in. layer of foam.

3. During digging operations, characteristics of the foamed areas will be recorded in the logbook including breakaway characteristics of the foam (within $1 \mathrm{ft}^{2}$ ) while digging is taking place, how much the foam sticks to or collects on the digging equipment, removed soil, and/or waste forms, and how often the foam blanket must be reapplied during digging. All of these observations will be noted in the project logbook.

The result of using the $3 \mathrm{M}$ Foam as a soil fixative on a large scale will be incorporated in the linal report, which will detail the performance and operation readiness of the CCU.

The use of 3M Foam as a soil fixative during the retricval demonstration will be supplemented by the use of potato starch in selected areas in the retrieval eells. The use of potato starch, which is also a soil tixative, will be in support of a Westinghouse Hanford work package sponsored by BWID. The potato starch will be applied to selected retrieval cells by the CCU. The coverage, conditions, and product performance will be documented using the same methods described for $3 \mathrm{M}$ Foam and the data provided to Westinghouse Hanford for their final report.

\subsubsection{Vacuum System Support}

The TRANSMATIC vacuum system in the CCU will be used to provide dust cleanup of equipment, working areas, and other materials that become dust laden from operations during the demonstration. Use of the vacuum system will be on an as-needed basis determined by the project 
scientists or field team leaders of the RES. While in operation, observations will be made and noted in the project logbook about the different areas and materials on which the vacuum system was used and its ability to clean the areas and materials. The vacuum system will be operated aceording to the procedures detailed in the operations manual of the CCU. Evaluation of the valuum system will be detailed in the final report describing the operation readiness of the CCU.

\subsection{Particulate Air Sampling}

A set of $47-\mathrm{mm}$ air particulate samplers will be located at strategic locations around the digging areas to collect air particulate dust samples. The number of samplers in use and their locations will depend on the task at hand. The purpose of eollecting air particulate samples is to evaluate the dust generation from a specific digging operation. It is not intended to evaluate the capabilities of the CCU or its products. This has already been done in past laboratory experiments.2

A diagram of a $47-\mathrm{mm}$ lilter sampler is shown in Figure 9. The 47-mm air particulate samplers will be connected to electronic mass llow sensors and rotary vane vacuum pumps to initiate and measure the flow through each sampler. The sampler flows will be between $4(0) 10801 \mathrm{pm}$ depending on the length of the sampling line. The electronic mass flow sensors will be connected 10 a datalogger and portable PC to record the air tlow through each sampler during testing. The sample filters will have been preweighed using methods detailed in later sections of this test plan. These results will be used to calculate a dust control efficiency $\left(C_{\text {eif }}\right)$ and control factor $(C F)$ for the misting system. The calculation methods used to calculate the $\mathrm{C}_{\mathrm{eff}}$ and $\mathrm{CF}$ can be found in Appendix $\mathrm{C}$ of this test plan.

Errors that could reduce the precision and accuracy of dust concentration measurements would include dropping the filter onto the ground before loading it into the sampler, touching the filter with bare hands when loading or unloading the filter from the sampler, dropping the sampler after dust collection and losing a portion of the accumulated dust, and placing the sampler too close to the misting heads where mist could be drawn into the sampler, decreasing the flow and efliciency of the sampler. As part of the sampling procedure, these situations will be avoided. There will be backup lillers, preweighed and labeled, in case a filter is dropped, damaged, or touched accidentally. The datalogger will display the llows every few seconds on the PC. If a filter or lube becomes plugged, the decrease in flow will be apparent from the datalogger display. If a sampler is dropped after or during dust collection. this datum will not be included for that particular lest. 

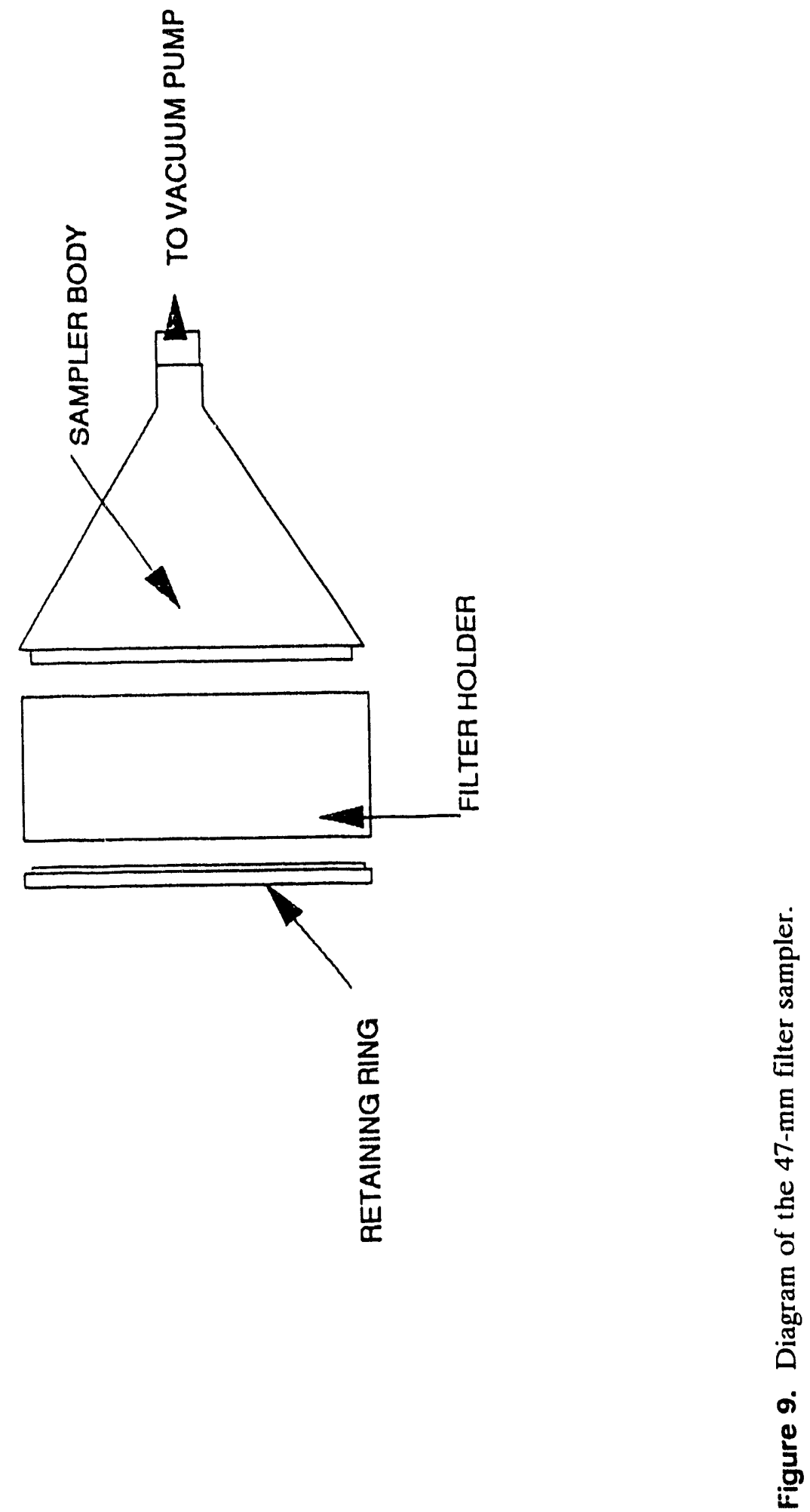
Presently, the sampling shelter is designed to accommodate 10 samplers. This was determined based on past experimental knowledge. 2,4 Because of the size of the areas to be sampled, 10 samplers were expected to be sufficient (and in some cases more than enough) to acquire good statistical data for each demonstration.

\subsubsection{Methods Used to Weigh and Handle Particulate Air Samples}

All filters will be weighed on a five place electronic balance that has been calibrated and approved by the EG\&G Idaho Standards and Calibrations Laboratory. All lilters will be preweighed at the INEL before transport to the Cold Test Pit to establish a baseline weight. The sampler filter shall be handled using tweezers to minimize contamination of the filter from moisture or natural skin oils from the hand. The filter will be placed on the balance, and the initial weight recorded in the project logbook. Each lilter will then be placed in a petri dish and sealed until used at the lacility. This method will be repeated for all filters. 


\section{SAMPLE CONTROL AND DOCUMENT MANAGEMENT}

Sample control will be maintained by placing all filters and smears in prenumbered petri-dishes after the initial weight is recorded using the system indicated below:

Sample ID $=P-X$

where

$\mathrm{P} \quad=$ particulate air filter

$\mathrm{X}=$ alpha numeric sample number.

The letter B will be placed following the sample ID number to denote background samples.

When a filter is used during testing, all pertinent data for that sample will be noted in the logbook as indicated. In addition, plot plans will be used from the work arca, pit working arca, equipment locations, and sampler locations. These plots will be included as inserts in the logbook. Each insert will be signed and dated.

A logbook will be kept during set-up and conduction of experiments. As a minimum, specific data that shall be included in the logbook for the work performed under this test plan are listed below:

1. Locations of samplers during all tests

2. Flow meter calibration information

3. Computer and datalogger setup information

4. Flow rates

5. Computer information including run identifiers, start times, disk file identifiers, and data storage information

6. Filter and smear pre and post-weights

7. Any changes made in experimental or electronic presets

8. Any test abnormalitics observed

9. Date and negative numbers of any photographs taken

10. Dates and information on all quality assurance samples (standards, blanks, and duplicates)

11. Any other pertinent information that the project scientist decms necessary 
12. Each page and entry into the logbook dated with the name of the person making the entry.

All data collected by the datalogger/PC will be saved on computer disk. Backups of all data and copies of all daily logbook entries will be made on a daily basis and given to the BWID project engineer for filing to ensure that data will not be lost.

This test plan and the procedures to carry it out will be followed as closely as possible. However, since this is only a test "plan," amendments or modifications to the plan will be made as necessary to attain :.$e$ best operation of the $\mathrm{CCU}$ and provide the best support to the demonstrations.

All modifications will be approved by the BWID site coordinator in advance and redlined into the operational test plan. 


\section{EQUIPMENT AND SUPPLIES}

The following is a list of sampling equipment and supplies.

1. 10 each McMillan 0 to $100 \mathrm{lpm}$ electronic tlow sensors

2. 2 each Gast $10 \mathrm{cfm}$ vacuum pump

3. Cables for datalogging sysicm

4. Omega model 481 datalogger

5. Compaq 286 portable PC

6. 10 each SAIC open lace $47-\mathrm{mm}$ particulate samplers

7. Sartorius ïive-place anaiytical balance

8. $500 \mathrm{ft}$ of $1 / 4$ in. diameter Dacron tubing

9. 100 each cellulose or glass fiber particulate filters

10. Swagelock fittings

11. Sampler stands

12. Sampling shelter

13. $30 \mathrm{~kW}$ portable generator.

The following is a list of miscellaneous equipment and supplies needed for conduction of the demonstrations and testing:

1. 4 misting stands

2. $50 \mathrm{kw}$ generator

3. 19- 5 gal pails of $3 \mathrm{M}$ Foam concentrate

4. $10-5$ gal pails of $3 \mathrm{M}$ Foam stabilizer

5. 4 - 55 gal drums of Flambinder

6. 11) -55 gal drums of XDCA (sugar beet polysaccharide)

7. 50 gal of potato starch product 
8. 10,000 gal water truck

9. Various hand tools for the $\mathrm{CCU}$ (e.g., pipe wrenches, screw drivers, crescent wrenches, etc.)

10. Personal protective equipment (PPE) for two people

11. Logbooks, 3.5 -in. diskettes

12. Extra hoses and nozzles for CCU systems

13. Chocks for trailer and generator. 


\section{SUPPLIES, UTILITIES, AND FACILITIES}

A $50 \mathrm{~kW}$ portable generator capable of producing $480 \mathrm{~V}$ is required for the operation of the CCU trailer. The generator is provided by Fleet Services at the INEL. A $20 \mathrm{~kW}$ portable generator capable of producing at least 70 anps at $120 \mathrm{~V}$ is required for the operation of the sampling shelter. A supplier has not been identified at the time of this writing.

A 10,000 -gal water truck is required to supplement the water supply of the CCU trailer during the field demonstration and during the support of the RES demonstrations. The water truck will be provided by the equipment pool from RWMC.

Equipment operators will be required to drive the truck to haul the CCU trailer, provide the water truck, and move the generators from place to place as necessary. The equipment operators will be supplied by the INEL (Central Facilities Area and RWMC). 


\section{QUALITY}

\subsection{Data Reduction and Analysis}

All data for each sample, such as the net filter weight and the total volume of air sampled, will be used to calculate an air particulate dust concentration and its conditions. Where possible, several samples collected in the same general area will be averaged to determine an average air particulate dust concentration for the work area. The conditions of each of the average concentrations can then be compared to compute a $\mathrm{C}_{\mathrm{eff}}$ and $\mathrm{CF}$ for each operation and condition. Methods for determining averages, standard deviations, $\mathrm{C}_{\mathrm{eff}}$, and CF, and their associated errors are found in Appendix $\mathrm{C}$ of this document. These results will then be compared to the test objectives to determine if the demonstration results were successful.

All equipment involved in collecting data will be calibrated before testing. This includes daily calibrations of the five place balance and semiannual calibrations of the flow sensors, flow meters, power supply, and high volume samplers. Data quality will be verified using peer review by the technical leader of the RM\&D Unit who is knowledgeable of data, assumptions, methodology, and individual measurements analysis to verify that data are within the performance specification as detailed in this test plan.

The acceptance criteria for CCU performance is based on the success of the systems in the CCU. Success will be determined from the comparison of the tests described in this test plan to previous studies done on these systems and products when tested individually. 2.4 


\section{SAFETY, TRAINING, AND LOGISTICS}

Safety is of utmost concern with all experiments. It is the policy of EG\&G Idaho to take every practical precaution to protect the health of the employees. Three areas of safety and training concerns are emphasized: radiological, field safety, laboratory, and waste management.

\subsection{Radiological Safety}

No work involving radioactive materials or work conducted in radioactively contaminated areas will be performed using this test plan.

\subsection{Field Safety}

All work performed in the field will be conducted in accordance to all applicable EG\&G Idaho and Enginecring Research and Applications standard practices. All personnel working in the field will need to have the following PPE:

- Steel toc salety shoes that at least cover the ankle

- Salety glasses with side shiclds

- Hard hat

- Hearing protection

- Leather gloves

- Industrial hygiene samplers capable of detecting the presence of $\mathrm{CO}_{2}, \mathrm{NOX}, \mathrm{CO}, \mathrm{NO}$.

In addition, personnel designaled as operators for the CCU will be required to wear the following PPE while using the foam and dust suppression agent application systems:

- White Tyvek coveralls (12.3 laminated)

- Face shicld

- Rubber boots and gloves

- Hearing protection or headset radios with ambient car protection

- Scoll air packs.

Special caution will be taken to avoid interlerence with the RES. No digging operations will be conducted while samplers and/or misting heads are being placed around the digging area or while foum is being applied. No CCU personnel will be permitted in the digging area during digging ()perations. 
Respiratory protection may be deemed necessary as directed by a cognizant industrial hygienist (IH). An IH professional shall be on hand during the initial phases of testing to determine when and what type of respiratory protection may be required while operating the CCU systems.

The following training will be required for personnel working in the field:

- $\quad$ Respiratory Protection with Self-contained Breathing Apparatus

- Hazard Communications

- Occupational Safcty and Health Administration Hazardous Waste Operator.

Laboratory safe practices are described in the EG\&G Idaho Standard Practices Manual, Section 2. Although this test plan is directed to field applications, these safe practices can be adapted to the field environment. Subsections that apply to this test plan in "General Laboratory Practices" include

- 1.5-Eye Protection and Protective Clothing

- 1.6-Laboratory Safety.

\subsection{Waste Management Practices and Training}

Waste management practices are described in EG\&G Idaho Safety Manual, Section 15 and "General Laboratory Practices," Section 2 of the Standard Practices Manual. Subsections of the "General Laboratory Practices" that apply (these practices will apply to both the laboratory and the ficld operations) to this test plan include

- 1.1-Non-Radioactive Chemical Waste Disposal

- 1.3-Chemical Lab Inventory

- 1.4-Chemical Spill Control

- 2.9-Handling and Storage of Hazardous Waste in Satellite Accumulation Areas.

Pertinent Safety Manual waste management practice subsections include

- 15.1-Routine Solid Waste Collection and Handling.

All wastes generated during operations described in this test plan will be handled and disposed of according to current company practices and state and Federal regulations. None of the materials used during these operations is considered hazardous and can be disposed of in a sanitary landfill. An environmental checklist has been submitted to DOE-ID and a categorical exclusion for the treatability study has been granted by DOE-ID. 


\section{REFERENCES}

1. S. W. Duce, M. R. Winberg, and A. L. Freeman, Basic Radiological Studies Contamination Control Experiments, EGG-WM-8272, September 1989.

2. M. R. Winberg and V. E. Wixom, Fugitive Dust Control Experiments Using Soil Fixatives on Vehicle Traffic Surfaces, EGG-WTD-10354, September 1992.

3. G. G. Loomis, D. E. Menkhaus, and D. W. Scott, "A System to Control Contamination During Retrieval of Buried TRU Waste," Waste Management 90, Tucson Arizona, February 25-March 2, 1990.

4. M. R. Winberg, R. J. Pawclko, N. C. Jacobs, and D. N. Thompson, Engineering Scale Dust Control Experiments, EGG-WTD-09387, 1991.

5. R. Hyde, Remote Excavation System Test Plan, EGG-WTD-10703, Rev, (), February 1993. 


\section{Appendix A \\ Operating Instructions for Model 70 Stabilized Foam Control Unit}




\section{Appendix A}

\section{Operating Instructions for Model $70^{\mathrm{a}}$ Stabilized Foam Control Unit}

The Model 70 is designed to apply stabilized foam using the 60 nozzle supplied with the unit. The chemicals utilized are 3M AFFF/ATC (FC-600) and 3M FS7000 stabilizer.

The FX9161 stabilizer is a water sensitive material and will solidify in approximately 1.5 minutes when introduced in water or vice versa. Therefore, the FX9161 container must not be opened until stabilized foam is to be made. Unit must be flushed, as described below, immediately after stabilized foam making is terminated.

To place unit in operation:

\section{READ CAREFULLY SAFETY PRECAUTIONS ON 3M AFFF/ATC AND FS7(MO) CONTAINERS}

1. Connect a $11 / 2$ in. National Standard fire hose to inlet of the unit, which is supplied with a 1 1/2 in. NST swivel. The water should be capable of supplying 80 PSI to 125 PSI at 70 GPM. Maximum inlet pressure is $200 \mathrm{PSI}$. Unit should not be operated above $125 \mathrm{PSI}$ control pressure.

2. Connect not more than two (2) $50 \mathrm{ft}$ sections of $11 / 2 \mathrm{in.}$ NST hose from outlet of unit to the nozzle. If more lengths of hose are required, $13 / 4 \mathrm{in.} \mathrm{hose} \mathrm{with} 11 / 2 \mathrm{in.} \mathrm{couplings}$ or 2 in. hose with $11 / 2$ in. couplings, may be used, up to a maximum length of $200 \mathrm{ft}$. Nozzle must not be elevated more than $10 \mathrm{ft}$ above the Model 70 control unit.

3. Close control valve on control unit, then open three turns, close flush valve.

4. Open water supply to unit and establish water flow through the unit and nozzle.

5. Adjust control valve to 80-85 PSI for maximum foam expansion (approximately twenty to onc). NOTE: As pressure is increased, expansion is reduced (at $125 \mathrm{PSI}$, expansion is approximately ten to one). Do not operate above 125 PSI inlet, as stabilized foam qualify will be reduced above that pressure.

6. Open one each 5 gal pail of FX9162 and FX9161, when stabilized foam is desired. Insert FX9162 suction hose (3/4 in. hose) into FX9162 pail, then FX9161 suction hose (1 in. hose) into the FX9161 pail.

a. Patent pending. 
Additional pails, as desired, inay then be opened and used to replace FX9161 and FX9162 as they are expended. Stabilized foam will have a light yellow color. The FX9161 concentrate pails must be protected from water when opened.

7. To cease operation, it is imperative that unit be flushed immediately after chemicals are expended. Not more than one minute should elapse from the ecessation of chemical flow to unit until the flush valve is opened.

To flusis the unit:

1. Remove both FX9162 and FX9162 pick up tubes from the respective 5 gal pails.

2. Open flush valve, water will flow in reverse from control unit through the FX9161 suction hose to atmosphere, foam followed by water will flow from nozzle.

3. When clear water is flowing from the suction hose and the nozzle (approximately two minutes) flush valve may be closed. Unit is now clear and may be reused or stored as desired. It is desirable, though not imperative, that a wet rag be used to wipe off the outside of the FX9161 suction hose while it is flushing, this will prevent a slow buildup of the material on the hose.

Note: Unit is supplied with two sets of suction hoses. Orifices which control chemical flow are installed in the respective hose assemblies, as supplied. If one becomes unusable due to chemical buildup, or other reasons, a replacement may he secured from Boots \& Coots at telephone number, 1-800-231-4613 during office hours. For emergency supply of loam, equipment, parts, technical information, or other assistance, use our 24 hr number which is, (713) 999-()276.

Williams Boots \& Coots Fire \& Protective Equipment, Inc. 3177 Summit Drive

Port Neches, Texas 77651

b. Low operating pressure is probable cause of flushing on the ATC line, which is no indication of a faulty unit. 
Appendix B

Vacuum System, Model DC5500 


\section{5500}

The DC 5500 is [ustcontrols most powernul mobile clusi exirathor. It is available in three difierent stanciarci models.

i. . . $\mathrm{kll}$ surable for spol extraction on large hand tools and heary cleaning

0.2kll's extremeiv strong vacumi efject and generally used in different types of malterial t ransporn systems and heavi cleaning where the coarse material is separated in a preseparator. Can be used with very long hose lengths.

6...til $P$ generates exiremely large flow and generally used in semi-moibite extraction systems. The machine is placed outdoors and connecled to a hose or semipermanent pipe system.

The DC 5500 has unique filter cleaning. The machines own necalive ;ressure is used in powver the rev erse pulse cleaning "stem. The nilters are cleaned effeclively with minimum wear. The machine is arailable also with an optional plastic container msteaci or the standiarci plastic bas. This nype is useful for apulications on nietai chips and shavings. cooling futids or jus1 soectal handing of recoverable materiais.

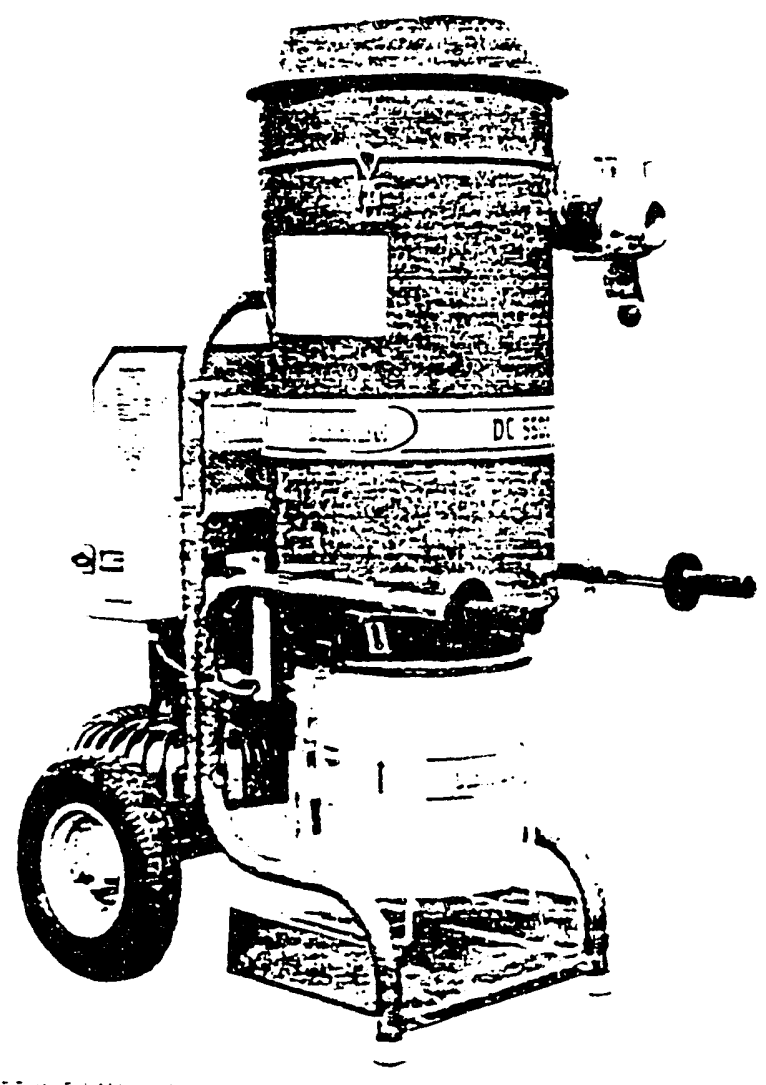

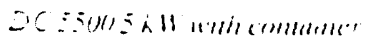

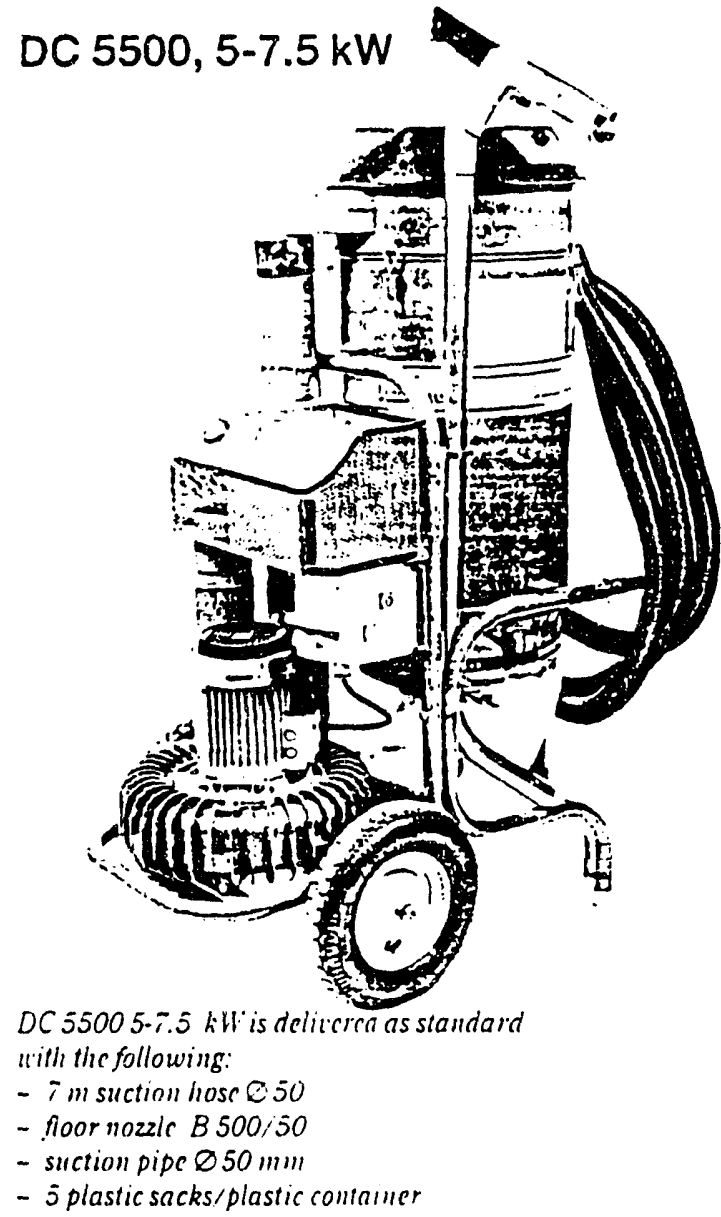

Part no Description

$1051005 \mathrm{~kW} 3 \mathrm{~s} 0 / 66 \mathrm{nl} 50 \mathrm{~Hz}$

105120 GE.5.5kil' $11.51^{\circ}$

105130 USA $7.5 \mathrm{~kW} 200 / 440 \mathrm{~N} 60 \mathrm{~Hz}$

105131 CANT.5 kll $6(3) 11 \% \mathrm{~Hz}$

$1051085 \mathrm{~kW} 380 / 6 \mathrm{k}(30)$ with container

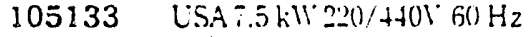

wilh comtaner 
Appendix C

Calculation Methods 



\section{Appendix C}

\section{Calculation Methods}

For each test sequence, a dust control factor (CF) and dust control efficiency $\left(\mathrm{C}_{\mathrm{eff}}\right)$ was calculated, where

$C F=C_{n} / C_{v}$

$C_{e f f} \%=1-\left[C_{v} / C_{n}\right] * 100$

where

$\mathrm{C}_{\mathrm{n}}=$ the average dust concentration at a particular sampler location in grams per liter with no soil fixative applied

$\mathrm{C}_{\mathrm{v}}=$ the average dust concentration at a particular sampler location in grams per liter for all test sequences with the soil fixative applied.

All averages and standard deviations for each sampler location were calculated by using the following equations:

$A V G=\left(\Sigma C_{i}\right) / N \quad$ (Note: This value was used as $\mathrm{C}_{\mathrm{n}}$ or $\mathrm{C}_{\mathrm{v}}$ depending on the test sequence.)

$\left.S T D=S Q R T / \Sigma\left(C_{i}-A V G\right)^{2} /(N-1)\right]$

where

$\mathrm{C}_{\mathrm{i}}=$ the concentration in grams per liter for each sample location for each test sequence performed

$\mathrm{N}=$ the number of times each test was run.

The standard deviation for the $\mathrm{CF}$ and $\mathrm{C}_{\text {eff }}$ is calculated as

$\left.S T D_{C F}=C F * S Q R T /\left(\sigma_{C n} / C_{n}\right)^{2}+\left(\sigma_{C v} / C_{v}\right)^{2}\right]$

$\left.S T D_{C e f f}=\left(100-C_{e f f}\right) * S Q R T /\left(\sigma_{C n} / C n\right)^{2}+\left(\sigma_{C v} / C_{v}\right)^{2}\right]$

where

$\sigma_{\mathrm{Cn}}=$ the standard deviation of the average dust concentration at a particular sampling location with no soil fixative applied 
$\sigma_{C V}=$ the standard deviation of the average dust concentration at a particular sampling location with the soil fixative applied.

This is a list of comments made by Jaffer and Alice on the Contamination Control Unit test plan. The comments will be stated and the response made in the test plan noted or explained.

1. It was mentioned that the CCU would support Waste Technology Development and should have stated the CCU would support BWID. This was corrected.

2. There was a question about whether there are wastes generated by BWID. 

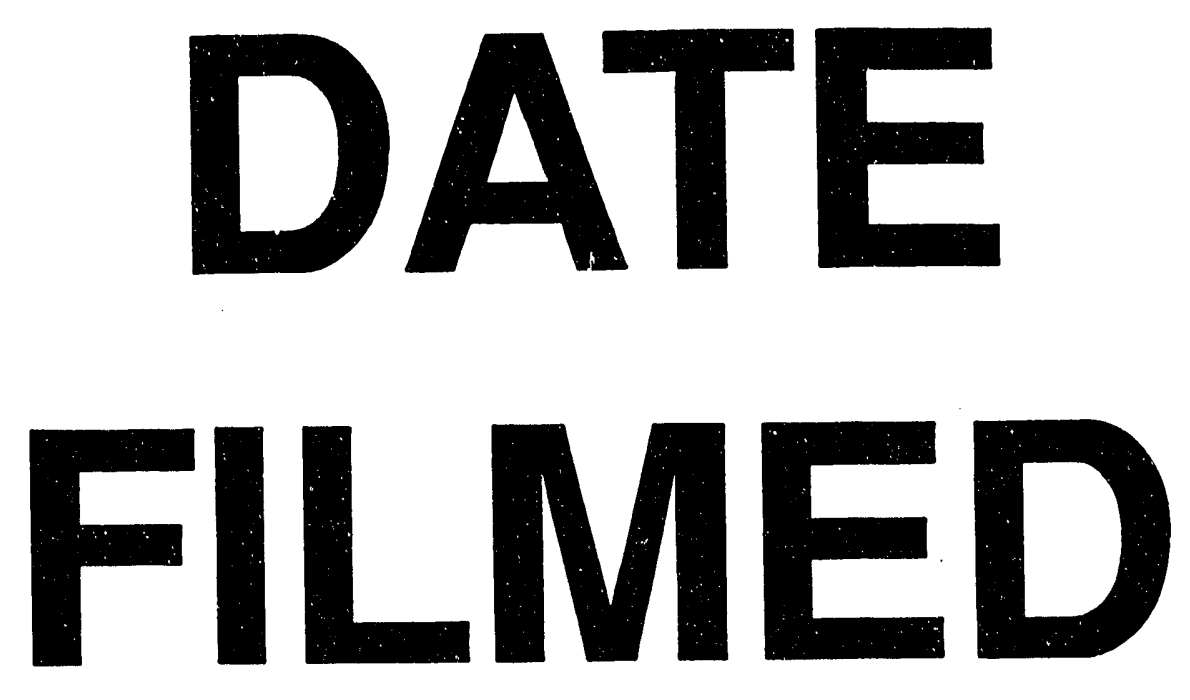

$8 / 17 / 93$
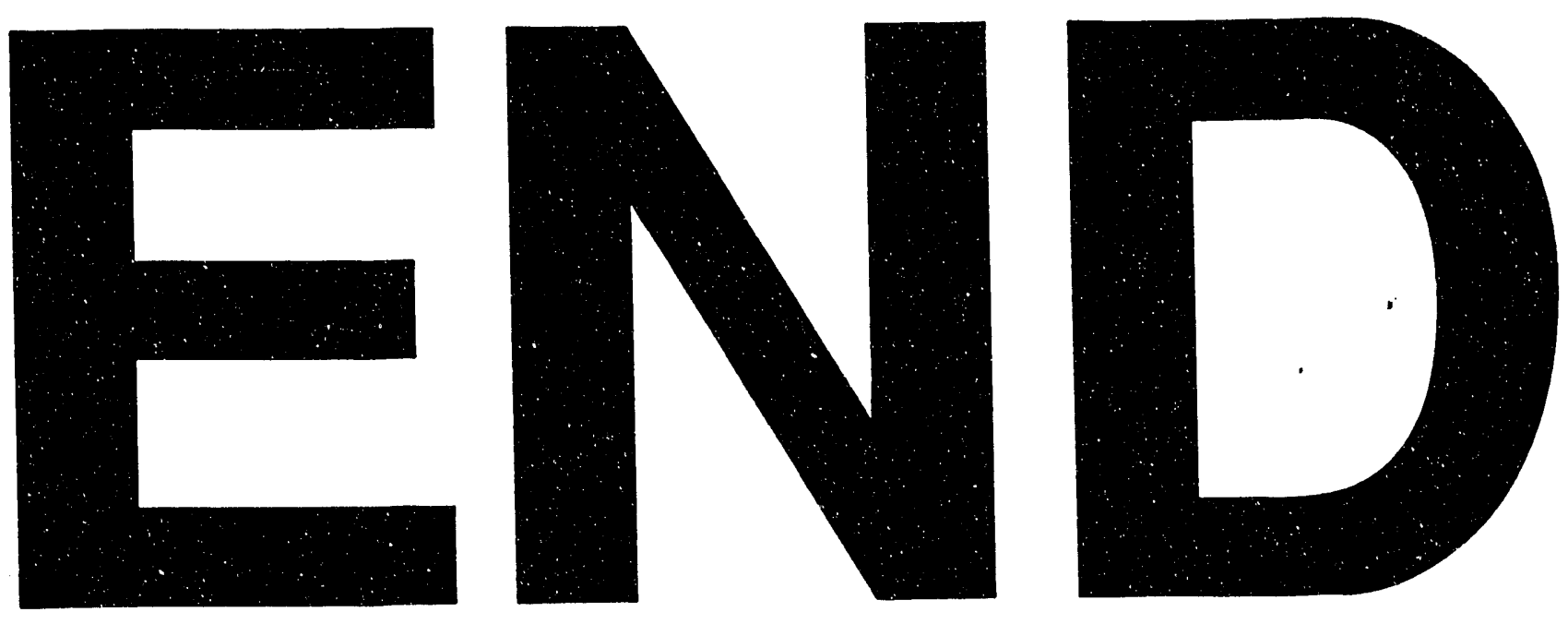
